\title{
Crustal and Mantle Sources at Various Settings of Phanerozoic Geodynamic Development Expressed in Volcanism and Metallogeny of Eurasian Active Margin
}

\author{
Vladimir I. Gugushvili \\ Department of Metallogeny, Al. Janelidze Institute of Geology, Iv. Javakhishvili Tbilisi State University, Jikia 16, Tbilisi 0186, \\ Georgia
}

\begin{abstract}
Phanerozoic geodynamic development of the Tethys ocean revealed at Eurasian active margin is manifested in pre- and post-collision stages. The Phanerozoic crust was already divided into sialic and basaltic crusts and rigid upper mantle. The precious and nonferrous metals were redistributed between them. In the sialic crust, precious metals are concentrated: $\mathrm{Au}, \mathrm{Ag}$ and $\mathrm{Pb}$, in basaltic crust_zinc, the copper mainly rests in the mantle. Phanerozoic plate-tectonics was manifested in the following settings: island arc, inter/backarc and oceanic. Island arc setting correlates with steady-state subduction and controlled by calc-alkaline volcanism. At this stage, the sialic, basaltic crust and mantle material participate in volcanism, whereas the subducted slab plunged in mantle, the metallogenic indicators are $\mathrm{Au}, \mathrm{Pb}, \mathrm{Zn}$ and $\mathrm{Cu}$. The stage of inter/backarc is related to steepening of subducting slab, because mantle diapir incursion provokes the rifting. At the initial stage and at stage of slackening rifting, when the sialic crust is not yet spread out from zone of volcanic activity, mineralization was represented by subalkaline trachydacites, shoshonite and alkali basaltic volcanism (volcanological indicators) and $\mathrm{Au}$ and $\mathrm{Pb}$ are participated with $\mathrm{Zn}$ and $\mathrm{Cu}$ in mineralization. The strengthening of steepening with mantle diapir incursion on higher level rifting spread out the sialic crust, volcanism on this stage is tholeiitic and mineralization is represented by zinc-copper-pyrite VMS (Volcanogenic Massive Sulphide) ores. The minor ocean setting is controlled by the most intensive spreading provoked by incursion mantle diapir at highest level, and spread out the basaltic crust as well, and volcanism belongs to ophiolites with dunite-peridotite magmatic activity. The mineralization was represented by copper-pyrite ores and single metallogenic indicator is the copper. The convergence of Eurasian and Afro-Arabian continents and closing of Tethys Ocean resulted in transferring the pre-collision stage in post-collision, characterized by trace elements Sb, W, Mo, $\mathrm{Hg}$, as geochemical and metallogenic indicator of the postcollision setting.
\end{abstract}

Key words: Pre-collision stage, volcanologic indicator, metallogenic indicator.

\section{Introduction}

The studied region is located in Iran, Caucasus, Turkey and Balkan-Carpathians represented by Tethys-Eurasian Metallogenenic Belt (Fig. 1). The Belt is represented by mineralization in Phanerozoic volcanic series and developed during convergence of Afro-Arabian and Eurasian continents at the evolution and closure of Tethys Ocean coincided with moving terranes teared from Afro-Arabian passive margin towards Eurasian active margin and their suturring

Corresponding author: Vladimir I. Gugushvili, Dr. Sci., Professor, research field: volcanology, metallogeny, geodynamic.
(Fig. 2). Two stages of geodynamic development are pre- and post-collision represented by appropriate volcanism, magmatism and mineralization. The pre-collision development is represented by island arc, inter/backarc and minor oceanic settings. Each of them is characterized by relevant volcanic activity and mineralization. The oceanic is represented by ophiolite volcanism and cupriferous Cyprus type ores, inter/backarc settings - by shoshonite, trachyandesite, tholeiite and subalkali olivine basaltic volcanism and $\mathrm{Cu}-\mathrm{Zn}$ pyrite mineralization, and the island arc setting by goldbearing lead-zinc-copper porphyry ore formation and epithermal low-sulfidation gold deposits. 




Fig. 1 Schematic structural map of the central part of the Alpean-Hymalayan belt and Tethys Eurasian metallogenic belt. Pre-collision subduction and spreading related porphyry, epithermal and volcanic massive sulfide deposits: 1 -Cheratepe, 2-Gumushane, 3-Baleli, 4-Chelopech, 5-Elatsite, 6-Elshitsa, 7-Bor, 8-Maidanpec, 9-Baia-Mare.

The post-collision stage occurred after closure of Tethys Ocean and stressing Afro-Arabian continent on the Eurasian margin, recorded in orogenesis, with formation of fold-thrust belt and smelting of granitoid magma from thick orogenic sialic crust. At the same time, high temperature fluids streamed along fold-thrust zone were leaching gold and trace metals ( $\mathrm{Sb}, \mathrm{W}, \mathrm{Mo}$ and $\mathrm{Hg}$ ) from the crust. The post-collision setting is characterized by significant gold-bearing copper-base metal mineralization and gold-antimonite, gold-sheelite and wolframite lodes and stockworks. At post-collision settings are known, also giant and most significant $\mathrm{Cu}-\mathrm{Mo}$ deposits. The mineralization coincides with trace metals ( $\mathrm{Sb}, \mathrm{W}, \mathrm{Mo}$ and $\mathrm{Hg}$ ) in the ore wall rocks widely spreading in the orebearing host rocks, so they are metallogenic and geochemical criteria of post-collision situation.
Diversity of distribution of trace, nonferrous and precious metals in the various geodynamic settings is depending on the scale of participation of sialic, basaltic and mantle sources during the process of volcanism and mineralization [1]. Such tendency is revealed at the Phanerozoic geodynamic evolution of Tethys Ocean, whereas in Archean and Paleoproterozoic when tectonics, magmatism and mineralization occurred in the relative buoyant lithosphere and were controlled by plume events, character and type of mineralization were different, related to plume influenced tectonics and characterized by high thermal flux and producing highly endowed Archean and Paleoproterozoic VHMS provinces and orogenic gold mineralization depended on redistribution gold and copper-base metals from mantle to granitic cratons during their formation. 


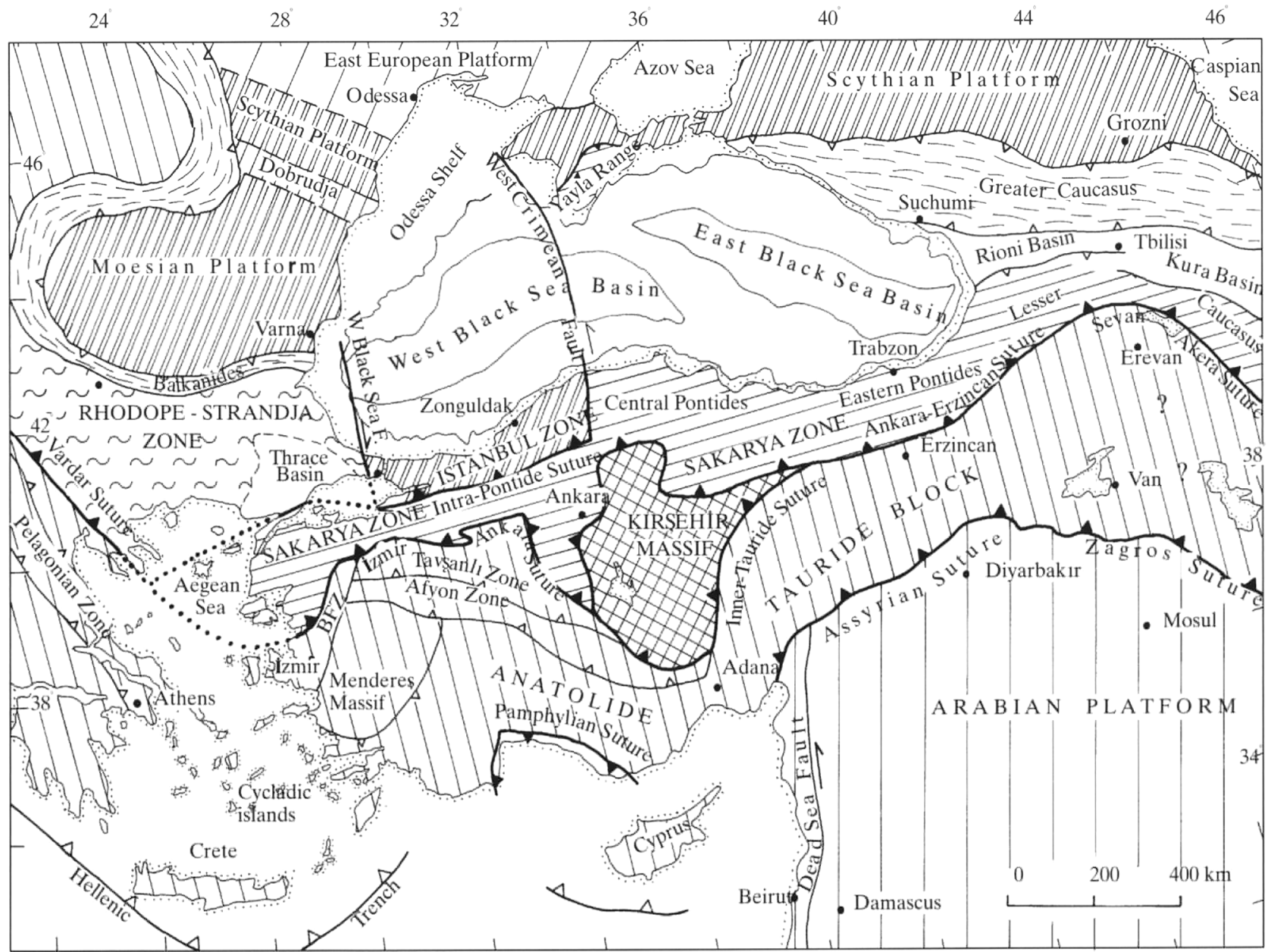

Fig. 2 Tectonic map of north-eastern Mediterranean region showing the major sutures and continental blocks. After Okay\&Tüysüs.

Important periods of formation of orogenic gold deposits, correlated with episodes of growth juvenile continental crust at (2.8-2.55 and 2.1-1.8 Ga) [2, 3].

So after Precambrian, in Phanerozoic, when the crust was divided in sialic, basaltic and rigid upper mantle, source of $\mathrm{Au}$ and $\mathrm{Pb}$ is sialic crust, source of $\mathrm{Zn}$ is basaltic and source of $\mathrm{Cu}$ is the mantle. In Phanerozoic during modern plate tectonics is related to new redistribution gold and base metal between deposits connected to various geodynamic settings, therefore Phanerozoic geodynamic development is controlled by volcanologic-petrological and metallogenic indicators confirmed by geochemical criteria related to scales of participation sialic, basaltic crusts and mantle in the various setting during plate tectonic evolution.
We will try to show evidence of above mentioned data on the concrete examples within studied region of the Tethys-Eurasian Metallogenic Belt.

\section{Volcanism and Mineralization in Island Arc and Incipient Stage of Inter Arc Settings}

The distinct example of the island-arcal and the incipient stage of interarc setting volcanism and mineralization with relevant volcanological and metallogenic indicators were established in the Bolnisi ore district of Lesser Caucasus (Georgia), in Figs. 3 and 4. The ore district presented two ore clusters: Madneuli and Beqtakari [4, 5]. Gold-copper-base metal deposits and ore manifestation of Madneuli cluster are distributed in Turonian-Conician (88-90 ma) calc-alkaline rhyodacite volcanic series (Mashavera 


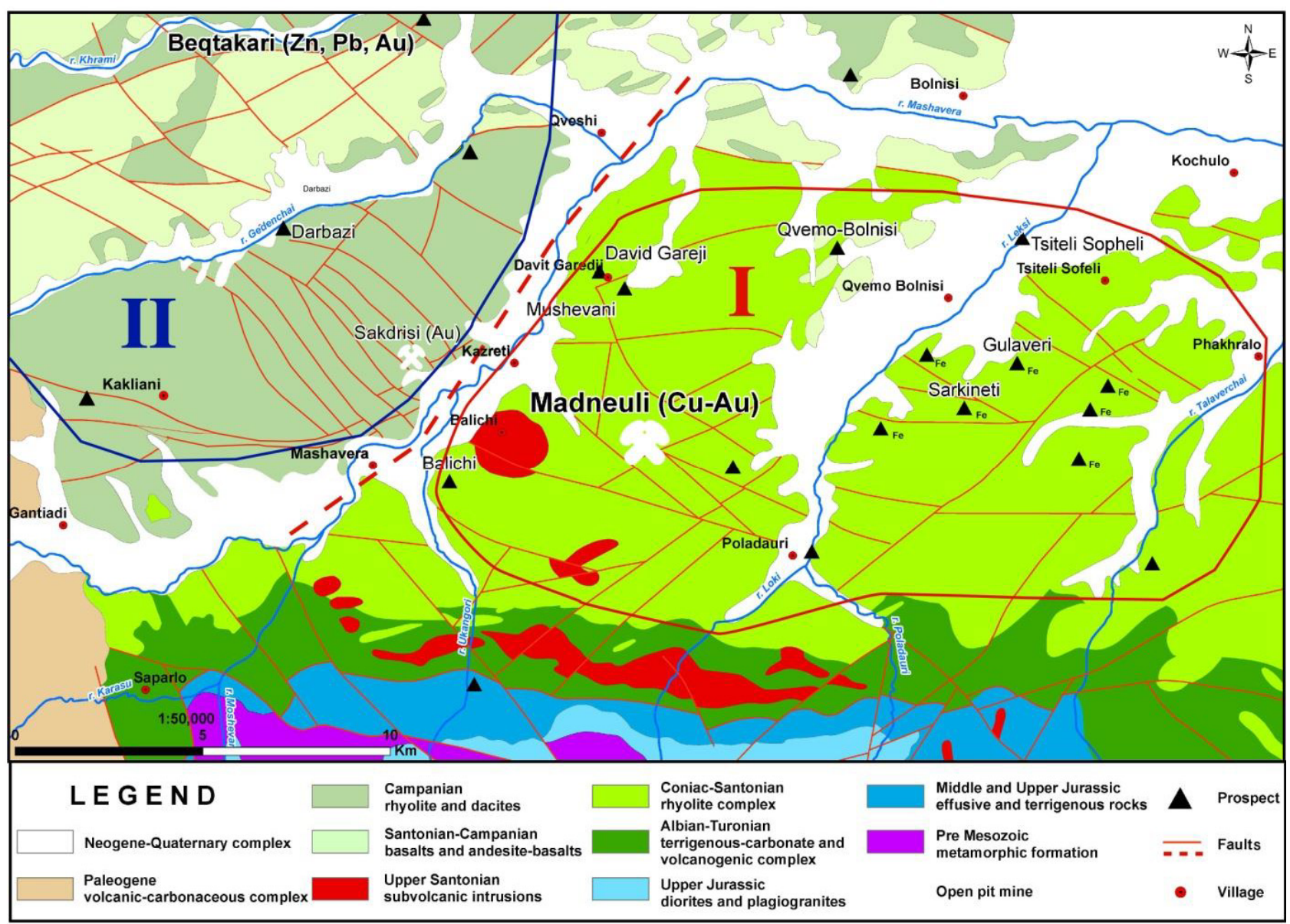

Fig. 3 Schematic map of the Bolnisi ore district I: Madneuli ore cluster; II: Beqtakari ore cluster.

suite) (Fig. 4). The background of hydrothermal alteration is chlorite-albite and zeolite propylitization. The ore forming here is preceded by silicification (secondary quartzites) substituted by gold-lead-copper-zinc pyrite porphyry and Kuroko type mineralization, upstears transferred in epithermal nonsulfide goldbearing quartz-chalcedony veins and stockworks (Fig. 5). Porphyry and epithermal mineralization here occurring at the islands emerged above sea level by intrusion of granodiorite stocks, later transferred into volcanic chambers. Explosion of ignimbrites was terminated by cauldron subsidence. The mineralization in the Madneuli ore cluster precedes ignimbrite ejections and cauldron subsidence. In the Madneuli open pit in ignimbrites the silicificated blocks is included with gold-copper base metal mineralization (Fig. 5) [6].
The Madneuli and Beqtakari clusters are divided by regional fault related to steepening of subducted slab (Fig. 3). Mineralization of Beqtakari cluster is distributed in Campanian (78-81 ma) Gasandami and Shorsholeti volcanic suites (Fig. 4). Here two types of mineralization and volcanic activity occurred. Gasandami suite is represented by trachyrhyolite and trachydacite volcanics. They are subjected by quartz-K-feldspath alteration with epithermal nonsulfide gold mineralization. The volcanic series are cut by trachyrhyolite extrusive domes. The Gasandami suite is overlaid by Shorsholeti volcanic series consisting of alkali olivine basalts subjected by of epidote-zoisite propylitization. At the same time the Campanian Gasandami suite is cut by gabbro-diabase intrusive stocks, which are the roots of Shorsholeti basaltic volcanic series. They are related with gold-copper-base metal mineralization, which 


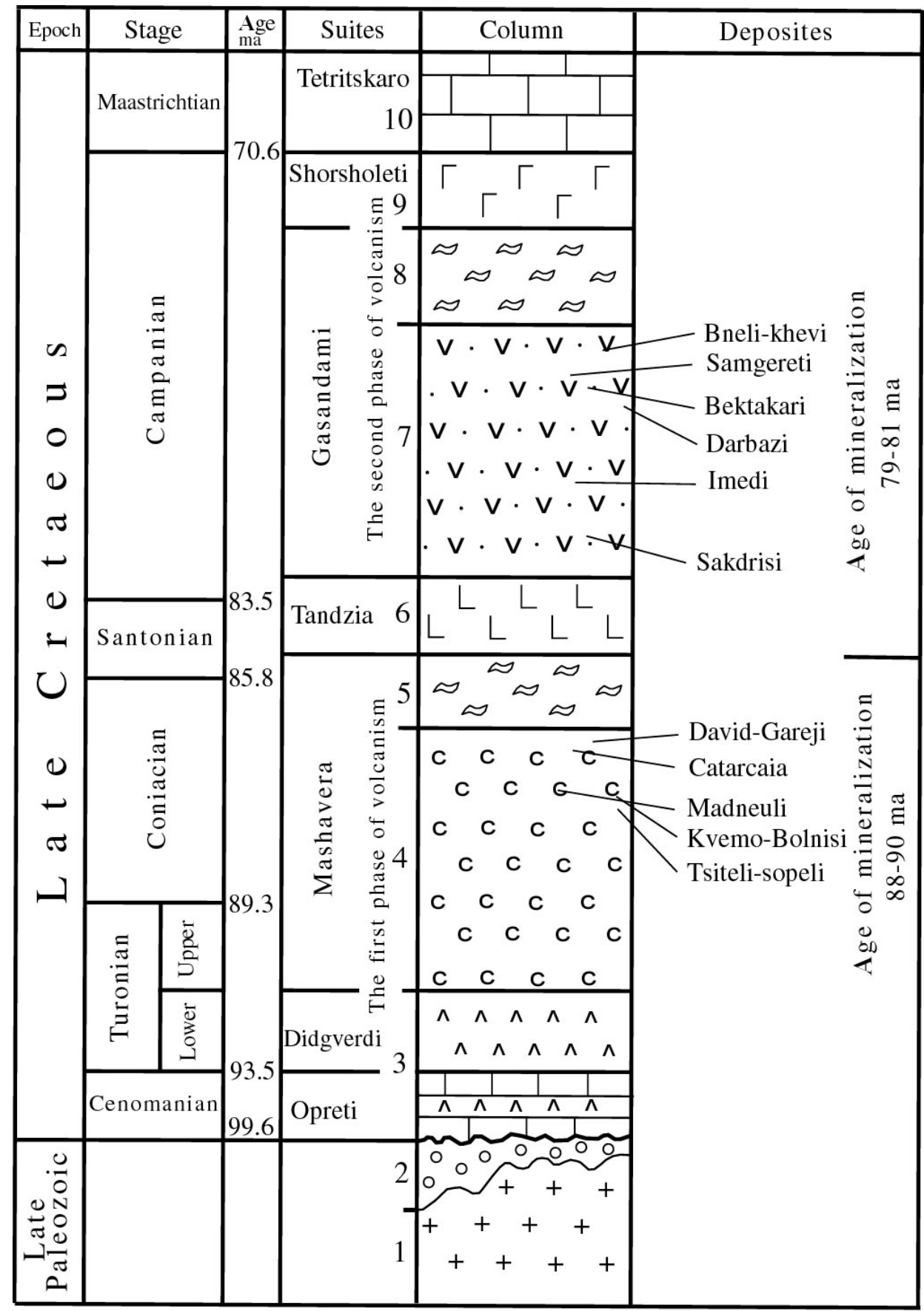

Fig. 4 Lithostratigraphic column of the Bolnisi ore district.

1: Paleozoic crystalline substratum. 2: Intraformation conglomerates. 3: Cenomanian-Turonian Opreti and Didgverdi suites - alternation of rhyodacite, andesite tuffs and limestones. 4, 5: Turonian-Lower Santonian Mashavera suite — rhyodacite tuffs, hyaloclastites tephroids, lava flows (4) and ignimbrites (5). 6: Upper Santonian-Campanian Tandzia suite-andesite-basalts and their tuffs. 7, 8: Campanian Gasandami suite-alternation of rhyolitic and rhyodacitic tuffs, volcano-sedimentary rocks and marls (7) ignimbrites (8). 9: Campanian Shorsholeti suite-alkali-olivine basalts and andesite-basalts. 10: Maastrichtian Tetritskaro suite-limestones. 


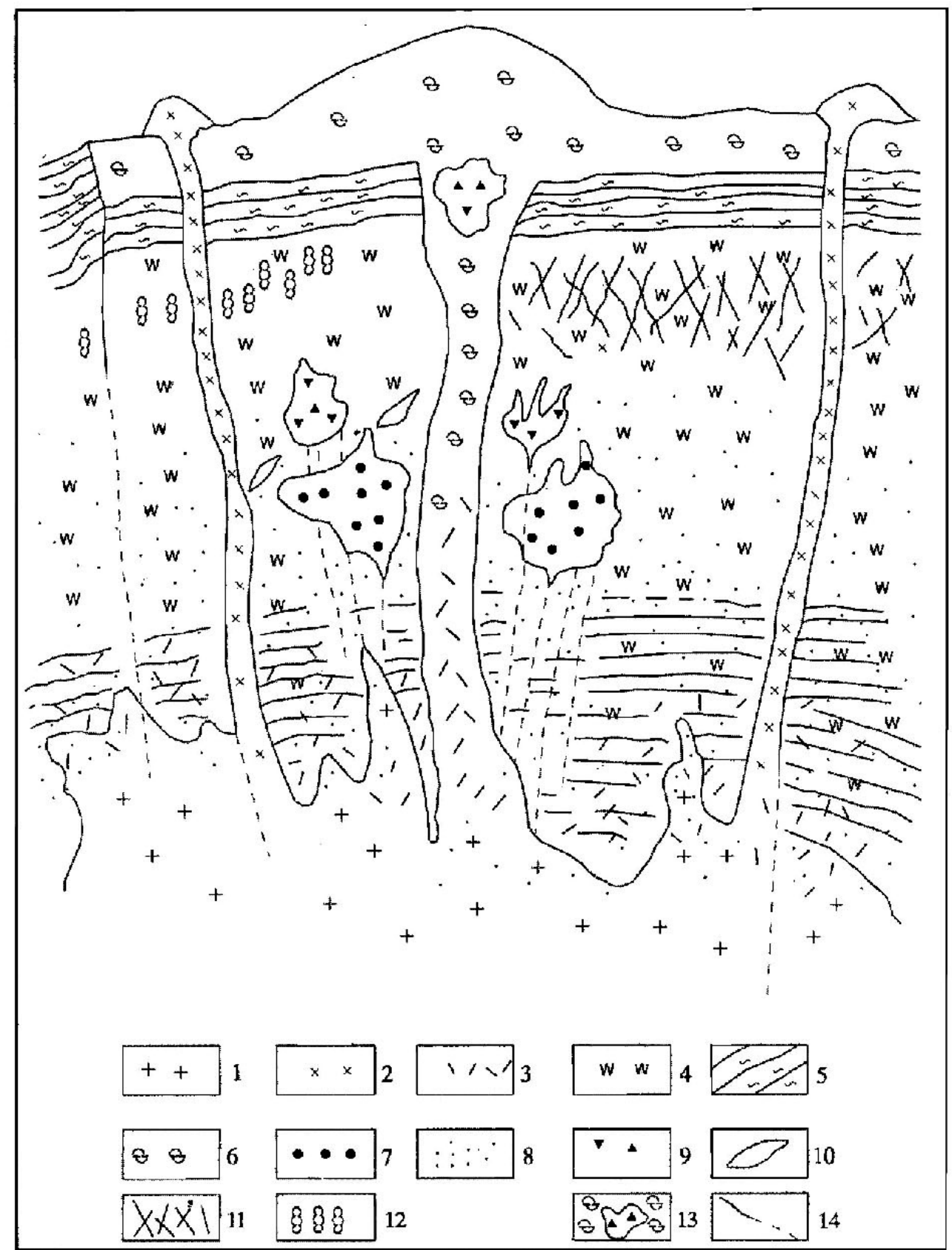

Fig. 5 Cross section of Madneuli deposit.

1: Granodiorite intrusive, 2: Rhyolite extrusive dome, 3: Sericitization, 4: Silicification, 5: Argillitization, 6: Ignimbrite, 7: Gold-copper-porphyry ore in hydrothermal breccia, 8: Gold-copper-porphyry disseminated poor ores, 9: Gold-barite base metal ores (in veins and hydrothermal breccia), 10: Copper-zinc ores, 11: Goldbearing nonsulfide gold mineralization in quartz-chalcedony veins and stockworks, 12: Nonsulfide gold mineralization in the quartz-barite veins and in cement of brecciated quartzites, 13: Xenolith of base metal ore in volcanic gorge, 14: Faults.

coincides with epidote-zoisite alteration substituted of quartz-K-feldspath metasomatites. So in the district of Beqtakari cluster two stages of initial inter-arc setting occur, controlled by initial steepening of subducting slab. At the first stage, when influence of mantle was a weak, subalkaly thrachyrhyodacite volcanism and goldbearing adularization occurred in Gasandami suite and at the second, after strengthening of mantle influence, alkali olivine basaltic volcanism of the Shorsholeti suite. Whereas in Turonian-Coniacian 
(Mashavera Suite) calc-alkaline rhyodacitic-andesite volcanic activity occurred. The Turonian-Coniacian volcanic series was subjected by pre-ore silicification and Au-base metal mineralization. It is noteworthy that $\mathrm{Au}, \mathrm{Pb}, \mathrm{Zn}$ and $\mathrm{Cu}$ participate in ores of Madneuli, so in Beqtakari cluster. Participation of gold and lead in ores of Beqtakari cluster maybe explained by weak spreading at the first initial stage of backarc setting and sialic crust was not yet spread out from the zone of volcanism and mineralization, and it participates in the oreforming process.

The similar situation is described in the Panagiurishte ore district (Bulgaria). Here also two ore clusters occurred according to steady state subduction and steepening of subducting slab controlled scales of participation crustal and mantle component in volcanic activity and mineralization [7]. The Chelopech, Elatsite, Medet and Asarel deposits are controlled by steady state subduction and are characterized predominantly by crustal influence on volcanism and mineralization, whereas in the Vlaysov-Vrukh, Elshitsa and Capitan Dimitriev deposits area, where steepening of subducting slab (roll back) would enhance, the incursion of astenospheric material and less crustally contaminated mantle melts occurred [7].

The metallogeny linked to steady state subduction and in an island arc setting was best developed during Late Jurassic and Cretaceous volcanism in the studied region. This is distinctly seen in Jurassic Gedaback, Alaverdi, Shamlug, Chovdar and Gosha $\mathrm{Ag}-\mathrm{Cu}$ porphyry and epithermal deposits, as well as at Madneuli cluster related to Cretaceous calc-alkaline volcanism ore bodies and the Dagkeseman group of deposits. The Eastern Pontides are represented by gold-copper-base metal-porphyry and low sulfidation, epithermal and Kuroko type deposits such as Madenkoy, Lahanos, Murgul Cheraepe, Guzelaila and Derekoy (Fig. 6) controlled by steady state subduction so as gold-copper-base metal mineralization in Balkans (Panagiurishte ore district) and Serbian

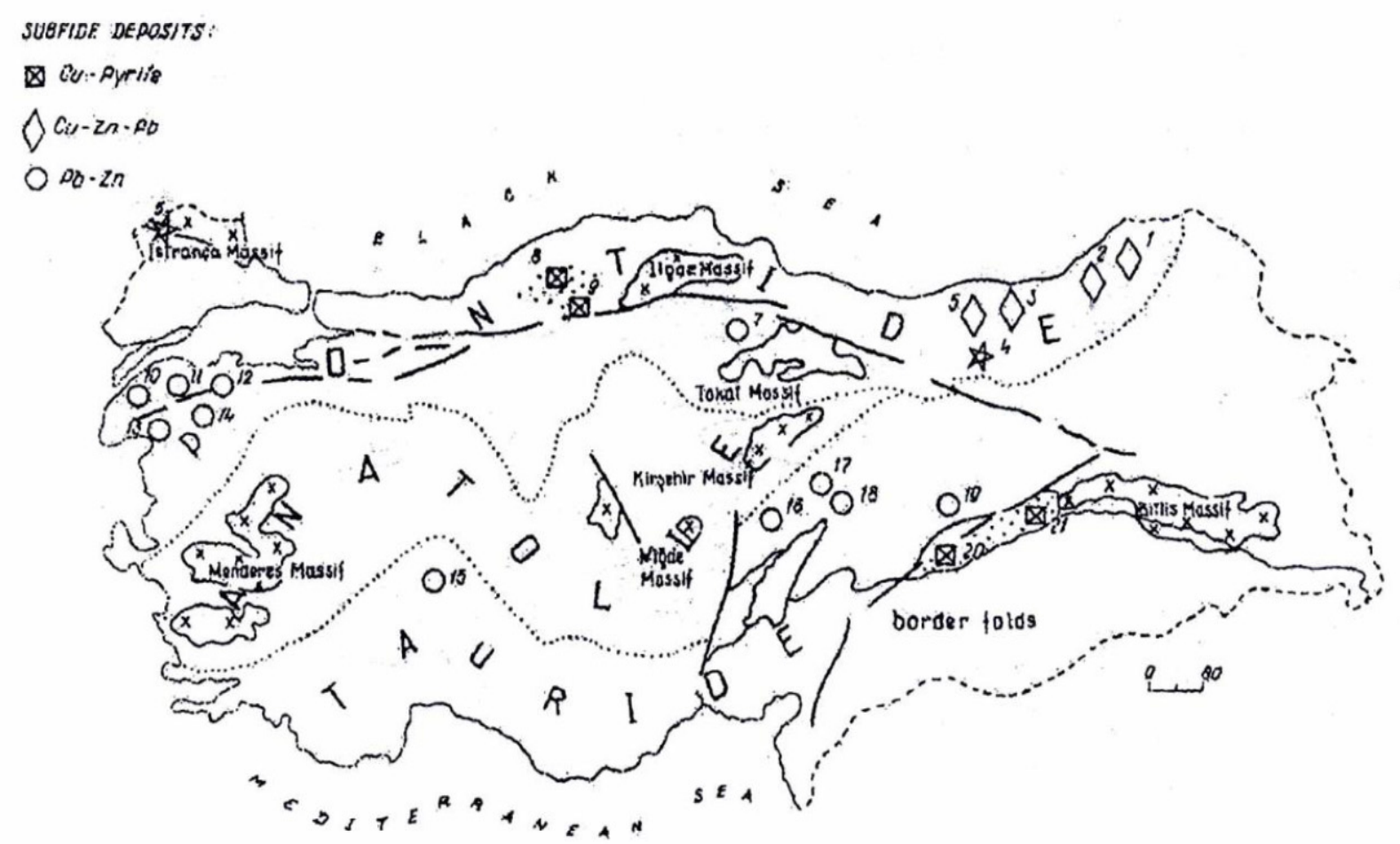

Fig. 6 Geotectonic scheme of Turkey with metallogeny of sulfide deposits [18].

Deposits: 1-Murgul, 2-Madenkoy, 3-Lahanos, 4-Guzelayla, 5-Derekoy (Kircaleli), 6-Cutlalar, 7-Akdagmeni, 8-Bakibaba (Küre),9-Ashikoy (Küre), 10-Arapchan, 11-Balya, 12-Demirbocu, 13-Altinoluk, 14-Kulakchitligi, 15-Bozkur, 16-Aladag, 17-Hyuilu, 18-Derekoy (Kaizery), 19-Keban (Elazig), 20-Maden (Elazig), 21—Madenkoy (Siirt). 




Fig. 7 Schematic geological map of the Srednegorie, Timok, Banat and Apuseni region with porphyry and epithermal mineralization [7].

Timok district copper-porphyry so as low sulfidation mineralization at Bor and Maidanpec [8,9] and copper-porphyry and epithermal deposits of the Romanian Carpathians (Fig. 7).

\section{Interarc-Backarc and Oceanic Settings, Volcanism and Mineralization}

The volcanism and mineralization of interarc setting distinctly exemplified in Forrange of Caucasus on Khudes group of deposits (Khudes, Yrup and Daud) distributed in the tholeiite-rhyolite the Paleozoic volcanic series. The mineralization of the deposits is copper-zinc-pyrite mineralization without gold and lead participation. The ore bearing tholeiites according to data of iron fractionation belong to abisal type; however, their $\mathrm{Ti}$ content and $\mathrm{K} / \mathrm{Rb}$ ratio are 
characterized for island arc tholeiites [10]. Such geochemical dualism is common for basalts of modern inter-arc rifts (New Georgia, Hebrides).

This part of Forrange of Caucasus is characterized with intensive rifting stipulated by incursion of mantle diapir at high levels and spreading out the sialic crust from area of volcanism and mineralization. So sialic crust does not participate here in volcanic activity and mineralization. It would be the reason of lack of gold and lead in the mineralization. Sources of $\mathrm{Zn}$ and $\mathrm{Cu}$ here are basaltic crust and mantle, so as subducting slab.

The example of backarc setting is the Early Jurassic backarc rift marginal sea of the Southern Slope of the Caucasus. It is represented by tholeiite volcanic activity concurrent turbidite sedimentation. Tholeiite volcanism is associated with Filiz-chai group of deposits (Filiz-chai, Catsdag, Kizildere, Adange). That is represented by chalcopyrite-pyrite-sppalerite-pyrhotite ores. Tholeiite is characterized by back-arc geochemical signature including low total REE (Rare Earth Elements), normal chondrite trend for $\mathrm{Nb}, \mathrm{Zr}$, Hf and $\mathrm{Y}$ and high content $\mathrm{Ni}$ and $\mathrm{Ti}[11,12]$. At the same time, ores of the Filiz-chai deposit contain minor quantity of gold and lead. The reason of their participation was the following: The bottom of the Early Jurassic sea was partly imbricated by remnants of sialic crust. The tholeiite extrusive events and turbidite sedimentation in the Early Jurassic occurred in area with remnants of thin continental crust [13] and this would be the source of minor gold and lead during the mineralization process. Source of zinc here, also, would be subducting slab and blocks of basaltic crust during the spreading, whereas the source of copper would be mainly mantle diapir which provoked the spreading.

The inter-arc setting recorded in the Eocene rifting occurred in Achara-Trialety zone of Lesser Caucasus (Fig. 8). The rifting here was related to steepening of subducting slab in Eocene and preceded of Cretaceous steady state subduction in the south-eastern Pontides and in Artvine-Bolnisi zone occurring in calc-alkaline volcanic activity and gold-copper base metal mineralization [14]. Calc-alkaline dacite-andesite volcanic activity was continued in Achara-Trialety zone in the Cretaceous.

Onset of rifting in the Achara-Trialety zone is marked by Paleocene turbidites (flysh) that grade up into Early Eocene shoshonite-trachyandesite volcanic series defined by the Peranga and Nagvarevi suites. The latter belong to early stage of inter-arc volcanic activity, related to incipient stage of mantle diapir incursion. The suits are implicated by a thick series of tholeiite-alkali-basalts (Chidila suite), an indicator of intensive rifting related to intensive upwelling of mantle diapir which provoked strong spreading. From the end of Middle Eocene to the Late Eocene, revival of the shoshonite-trachyandesite volcanic activity took place and was followed by deposition of the Adigeny and Upper Adigeny suites above the Chidila suite, that indicated the slackening of rifting. The background alteration in Chidila suite is represented by epidot-chlorite high temperature propylitization, which is transferred in shoshonite-trachyandesite volcanic series (Adigeny and Upper Adigeny suites) with less temperature chlorite-albite and zeolite propylitization.

It is different from tholeiite series of Forrange of Caucasus where significant VMS $\mathrm{Zn}-\mathrm{Cu}$ pyrite mineralization occurred in Achara-Trialety to thick $(5,000 \mathrm{~m})$ tholeiitic Chidila suite no VMS mineralization is known. The reason would be anomalously high content of copper and zinc in the tholeiites. They were concentrated in magma and did not transfer in the fluid phase [4, 5]. A similar situation is described in basalts of South Ural intra-arc rifts, that are also anomalously rich in copper and zinc, but there is not known stratiform mineralization [15]. The authors also argue, that the magma was rich in the metals, but did not transfer into a magmatic hydrothermal fluids. 


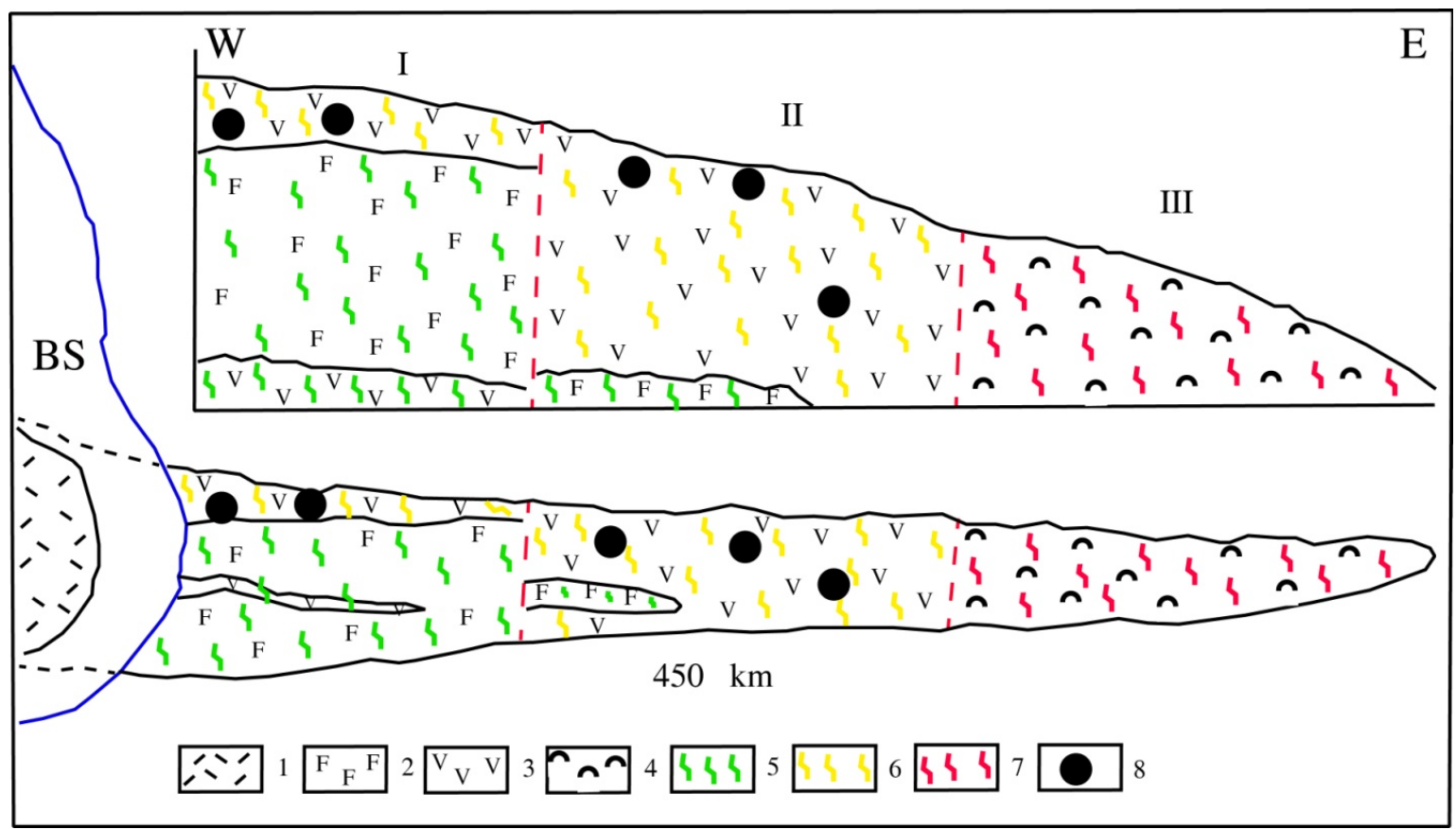

Fig. 8 Schematic map and cross section of the Eocene volcanic series of Achara-Thrialety zone.

1: Ophiolites, 2: Tholeiite and alkali basalts, 3: Shoshonite-trachyandesite series, 4: Andesite series. 5: Epidote-zoisite propylitization, 6: Chlorite-albite propylitization, 7: Zeolite propylitization, 8: Gold-copper-base metal mineralization. I: West segment, II: Central segment, III: East segment.

The most intensive spreading and incursion of mantle diaper on the highest level coased the minor ocean setting. The Paleozoic minor ocean setting was described in the Central Pontides (Turkey) (Fig. 6) as Paleozoic-Early Mesozoic Küre Complex [16]. It was evolved as a result of transferring backarc into minor ocean setting above N-NW subducting slab of the Tethys ocean. It consists of ophiolite and MORB tholeiites extrusions, their oceanic nature confirmed by geochemistry of mobile elements. The complex consists of serpentinized peridotites, overlined by layered cumulates gabbro's passing upward into isotopic microgabbro. The latter is overlined by alternation of pillow and massive lava flows and lava-breccias. Lava-breccia itself is overlaide by semipelagic shales. The Küre Complex contain cupriferrous mineralization-characteristic for oceanic setting, presented by copper-pyrite deposits Asikoi and Bakibaba (Fig. 6) [16]. According to Guner [17], they are presented as by disseminated, and massive ores and are located along contact of lava-sedimentary rocks. In copper-pyrite mineralization $\mathrm{Au}, \mathrm{Zn}$ and $\mathrm{Pb}$ present only as trace elements. Here, the sialic and basaltic crusts were spread out from zone of volcanism and mineralization, therefore here volcanism and ore formation had only mantle source. So, metallogenic indicator here is only copper, volcanologic and petrologic indicators are ophiolites and dunite-peridotite, whereas indicator of hydrothermal alteration is serpentinization.

The other oceanic setting, represented by ophiolites, is divided by Borderfield and Tauride terrannes (Fig. 6). This ophiolite comprises eastern flank of the Cyprus ophiolitic belt and consists of pillow lavas, gabbro-dunites, pyroxenite, verlite, hartzburgite, dunite and diabas dikes [18]. Here, copper-pyrite Cyprus type VMS deposits are known: Madenkoy (Siirt) and Maden (Elazig), due to lack of $\mathrm{Au}, \mathrm{Pb}$ and $\mathrm{Zn}$. It is confirmed, that oceanic ores consist of mainly copper and its source in Phanerozoic is the mantle. So in backarc rifts and oceanic setting gold is known only in trace amount and it is confirmed, also, by data of 


\section{Crustal and Mantle Sources at Various Settings of Phanerozoic Geodynamic Development Expressed in Volcanism and Metallogeny of Eurasian Active Margin}

Rona and Scott [19], which completely rulled out participation of sialic crust in oceanic setting.

The idealized scheme of interrelation of volcanism and mineralization at various stages of subduction of Tethys ocean slab is presented in Fig. 9. Here it is shown, that volcanologic indicator of steady state subduction in calc-alkaline (andesite-rhyodacite) volcanics and metallogenic indicator is $\mathrm{Au}, \mathrm{Pb}$, $\mathrm{Zn}$ and $\mathrm{Cu}$ mineralization (Fig. 9I); In the initial stage of interarc-backarc setting volcanological indicator is trachy-rhyodacite and trachy-olivine basaltic volcanic activity, whereas metallogenic indicator is $\mathrm{Au}, \mathrm{Pb}, \mathrm{Zn}, \mathrm{Cu}$ mineralization with high grade of gold (Fig. 9II), reasoned by higher temperature of alkali fluids, than in steady state subduction stage, whereas alkaly character of volcanic is reasoned by influence of the mantle diapir. The participation of gold and lead may be explained by sialic crust source of $\mathrm{Au}$ and $\mathrm{Pb}$ participation in initial stage of interarc-backarc setting. The strengthening of incursion of mantle diapir at the stage of interarc-backarc rifting stipulated the spread out of sialic crust from the zone of volcanic activity determined participation of the basaltic crust and mantle material, was caused by tholeiite volcanism and $\mathrm{Cu}-\mathrm{Zn}$ mineralization, and lack of gold and lead was volcanologic and metallogenic indicators of this stage of development (Fig. 9III).

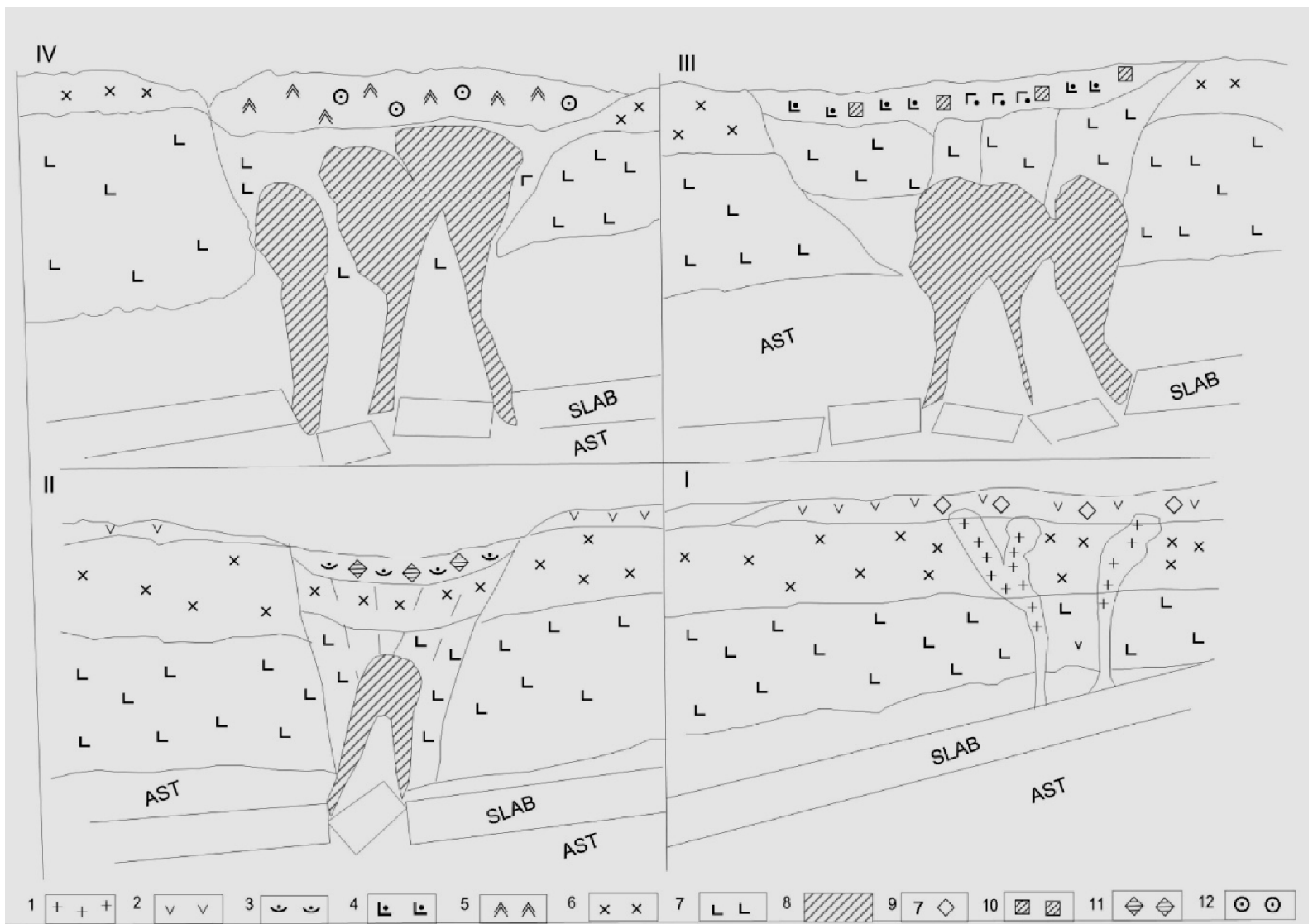

Fig. 9 Idealized scheme of interrelation of volcanism and mineralization at various stages of subduction of the Tethys ocean slab.

I-Steady state subduction and island arc setting, II-Incipient stage of steepening of subducting slab, III-Reinforcement steepening and backarc-interarc setting, IV-Intensive spreading and minor ocean setting.

1: granodiorite stocks, 2: calc-alkaline rhyodacite volcanics, 3: trachy-rhyodacite and alkali olivine basalt and trachybasalt volcanics, 4: olivine basalt and tholeiite volcanics, 5: ophiolite volcanics and dunite-peridotite intrusive bodies, 6: sialic crust, 7: basaltic crust, 8: mantle diapir, 9: Au-Pb-Zn-Cu mineralization, 10: $\mathrm{Au}-\mathrm{Pb}-\mathrm{Zn}-\mathrm{Cu}$ mineralization with high grade of gold, 11: $\mathrm{Zn}-\mathrm{Cu} \mathrm{VHMS}$ ores, 12: Cu-pyrite Cyprus type ores. 
The further strengthening of mantle diaper incursion at highest level determined spread out of basaltic crust (source of $\mathrm{Zn}$ ), transferring the backarc setting into minor ocean (Fig. 9IV). At this stage, the volcanism and mineralization were fed only by mantle and volcanological and petrological indicators are represented by ophiolite volcanic activity, dunite-peridotite magmatism and serpentinization, whereas metallogenic indicator is only $\mathrm{Cu}$ in copper-pyrite Cyprus type mineralization.

\section{The Temporal and Spatial Relationship of Subduction with Volcanism and Mineralization at Pre-collision Stage of Development}

During subduction oceanic slab temporally and spatially tend to steepen and mantle diapir incursion of various intensity caused alternation of island arc, back/interarc and minor ocean settings, occurred along and laterally to dipping of slab, as well as temporally in ascending succession. The shifting of geodynamic settings is distinctly seen in the Caucasus region (Fig. 10). The first Paleozoic stage of subduction is displayed in the Bechasin zone of North Caucasus related to island arc setting that occurred in calc-alkaline andesite-dacitic volcanism and coincided with $\mathrm{Au}, \mathrm{Pb}, \mathrm{Zn}$ and $\mathrm{Cu}$ porphyry and disseminated mineralization. To the north in the Forrange of Caucasus, the steepening of subducting slab is connected to incursion of mantle diapir which caused spreading and formation of Paleozoic interarc setting (Fig. 10I). Tholeiitic volcanic activity here was associated with deposition of the Khudes group (Khudes, Urup, Daud) of $\mathrm{Cu}-\mathrm{Zn}$-pyrite deposits. The tholeiites according to iron fractionation data belong to abisal type; however, by their Ti content and $\mathrm{K} / \mathrm{Rb}$ ratio they are attributed to island arcal tholeiites [10]. Such geochemical dualism is common to modern interarc rifts (New Georgia, Hebrides). Khudes group of deposits consists of copper-zinc/pyrite ores without gold and lead. Source of zinc here would be subducting slab and spreading basaltic crust, whereas source of copper is the mantle. It is noteworthy, that sialic crust was spreading out and not involved in mineralization and it must be reason for absence of gold and lead in the ores. The Paleozoic interarc rifting to the south was preceded by the northverging steady state subduction of Bechasin zone with suprasubduction calc-alkaline volcanism and related $\mathrm{Au}, \mathrm{Pb}, \mathrm{Zn}$ and $\mathrm{Cu}$ mineralization.

At the Early Jurassic backarc setting was developed at Southern Slope of the Great Caucasus represented as a marginal sea setting [20] (Fig. 10II). The tholeiite volcanic activity here is concurrent with turbidite sedimentation. The associated Filiz-chai deposits (Filiz-chai, Catsdag, Kizildere, Adange) consist of stratiform VMS type pyrite-chalcopyrite-sphalerite-pyrhotite ores. Orebearing tholeiites are characterized by as a backarc geochemical signature, so by volcanological and matallogenic indicators. The ore contains minor quantity of gold and lead reasoned to participation remnants of thin sialic crust, and would be source of gold and lead during mineralization. The formation of an Early Jurassic backarc and marginal sea predates Paleozoic-Triassic-Early Jurassic subduction and related calc-alkaline dacite-rhyolite volcanism that formed the rocks of Narula suite overlaid the Paleozoic granite-metamorphic complex of Dzirula Salient in the Transcaucasus [20].

Calc-alkaline volcanic rocks of the Middle Jurassic (Bajosian) island arc in the Transcaucasus alternate with Late Jurassic alkali olivine basalt and trachyandesite suite is cut by monchikite and camptonite extrusions [21]. In the Rioni river, depression drilling lately exposed the thick $(>2,200 \mathrm{~m})$ Kimerije-Tittonian Upper Jurassic volcanic suite of tholeiite, highly titanous olivine basalts and trachites [22]. M. Lordkipanidze attributed them to interplate rifting, which we relate to an astenospheric upwelling. Southwards, in the Locki-Garabakh zone of the Lesser Caucasus exposed calc-alkaline volcanic rocks may be 




Fig. 10 Pre- and post-collision development and metallogeny exemplified in the Caucasus region.

1 - subducted slab, 2-basaltic crust, 3-sialic crust, 4-calc-alkaline volcanic series, 5-shoshonite series, 6-tholeiite and alkali olivine basalt series, 7-VMS mineralization, 8-granodiorite porphyry, 9-fold-trust zone, 10-faults. BS-Black Sea, CS-Caspian Sea, GC-Great Caucasus, SSC-Southern Slope of Caucasus, TC-Transcaucasus, AT-Achara-Trialety, LS — Lesser Caucasus, EP_East Pontides, BSMO_Black Sea Minor Ocean, T—Talysh. Precollision mineralization: $\diamond-\mathrm{Au}, \mathrm{Pb}, \mathrm{Cu}$, $\mathrm{Zn}$; ○- Pb, Zn; $\square-\mathrm{Zn}, \mathrm{Cu}$; Postcollision mineralization: 

Volcanism and Metallogeny of Eurasian Active Margin

related to steady state northvergent subduction, which, with steepening of the subducted slab, shifted the magmatism into tholeiite-basalts of backarc setting.

In the Locki-Garabakh zone, significant gold-copper-base metal mineralization of Shamlug, Alaverdy, Tekhut, Gedabeck, Karadag and Chovdar deposits related to calc-alkaline volcanism represented porphyry, epithermal and VMS systems of mineralization [23] to the north in the Transcaucasus steepening of subducted slab and rising asthenosphere transferred into Late Jurassic alkali-basalt backarc volcanism. It was preceded in the Locki-Garabakh zone by Late Jurassic calc-alkaline volcanic activity and mineralization (Fig. 10III).

A similar situation occurred in Transcaucasus in the Cretaceous (Fig. 10IV), where the Turonian-Santonian Mtavari volcanic suite consists of picrite-basalts, alkali olivine basalts, trachyandesites and trachites are cut by phonolite extrusions [21, 24]. According to petrochemical and geochemical indicators, these rocks belong to a backarc volcanic series. At the same time to the south, in Artvine-Bolnisi and Loki-Garabakh zones, a Late Cretaceous calc-alkaline volcanic series was controlled by steady state subduction.

Gold-copper porphyry and low and high sulfidation epithermal deposits in the Caucasus, Eastern Pontides, Balkans and Carpathians are related to the subduction. At the same time, similar deposits are distributed as in the Bolnisi district of the Lesser Caucasus, also in Panaguirishte region of Bulgarian Srednegorie. In the Bolnisi ore district Campanian marked the beginning of the first stage of slab steepening, roll back, break-off and incursion of rising asthenosphere as the setting changed from island arc to an incipient stage of backarc. It is recorded in the formation of Shorsholeti suite and related metallogeny. The suite consists of high-magnesial alkali olivine basalts and trachiandesites with petrochemical and geochemical characteristic attributed to backarc setting. To the north in Transcaucasus, the subducting slab was subjected to further steepening by mantle influence and volcanic activity was represented by picrite-basalts, olivine basalts and phonolites of the Mtavari suite (Fig. 10IV).

The steepening of subducting slab and astenospheric upwelling continued in the Eocene. This is clearly observed in the Achara-Trialety rift. Slab steepening and rifting in Eocene was preceded by steady state subduction, island arc volcanic activity and gold-copper-base metal mineralization [14] (Fig. $10 \mathrm{~V})$. At the same time, in the Achara-Trialety zone laterally from the west to east, steepening of the slab and rising asthenosphere was diminished with further transformation to the steady state subduction (Fig. 9).

Achara-Trialety belongs to mobile system of the Eurasian active margin. Here distinctly temporal and spatial development was seen along dipping of slab, so laterally to dipping and temporally in ascending succession.

The Achara-Trialety zone is divided into three segments: western, central and eastern [22]. The onset of rifting in the Achara-Trialety area is marked by Paleocene turbidites (flysch) that grade upward into Early Eocene shoshonite-trachyandesite volcanic series defined by the Peranga and Nagvarevi suites. The latter belong to an incipient stage of interarc volcanic activity related to first stage of mantle diapir incursion. They are imbricated by thick series $(5,000$ $\mathrm{m})$ of tholeiite and alkali basalts (Chidila suite), an indicator of intense mantle upwelling during spreading. Lately in Eocene revival of shoshonite-trachyandesite volcanic activity took place and was followed by deposition of Adigeny and Upper Adigeny suites above Chidila suite that indicated the slackening of rifting. In the Central segment (Achara-Imereti ridge and Akhaltsikhe depression) intensity of rifting was diminished and caused the shoshonitic-trachyandesite-dellenite volcanic event. The thickness of the Eocene series here is reduced. In the western segment it was $7 \mathrm{~km}$ thick, in the central it is decreased to $4 \mathrm{~km}$. To east, in Trialety ridge area the average thickness, where rifting 


\section{Crustal and Mantle Sources at Various Settings of Phanerozoic Geodynamic Development Expressed in 375 Volcanism and Metallogeny of Eurasian Active Margin}

was waned and volcanic series consists of calc-alkaline andesites, was only $2.5-3 \mathrm{~km}$. So, here interarc was transferred into island arc setting. The geochemistry and petrochemical characteristics of volcanic units in Achara-Trialety zone indicate that the rifting was slackening from west to east, with transition of interarc into an island arc setting [11].

The lateral transition of interarc to island arc setting depended on slackening of asthenospheric incursion and laterally the dipping of slab across the segments from western via central to eastern caused by slackening of steepening northvergent subducting slab along its dipping from west to east. In the east segment the steady state subduction occurred which stipulated island arc setting.

The interarc rift in the western segment of the Achara-Trialety zone continues the Black Sea minor ocean basin [25] (Fig. 11). The minor ocean basin itself extends to west in the Burgas syncline (Bulgaria), which is underlaid by tholeiite and alkali basalts [26]. The volcanic sequence in Burgas is similar to that of Achara-Trialety interarc rift.
A similar situation occurs in Azerbaijan, where the Middle-Late Eocene Talysh backarc continues to the Caspian Sea [27] (Fig. 11). The Talysh backarc is bordered to Ankara-Erzinjan-Sevan suture and its formation is related to Tethys Ocean subduction and steepening of subducted slab. It is bordered by Eocene Albortz-Azerbaijan trachyandesite rocks imbricated on the Cretaceous calc-alkaline andesite-dacite volcanic rocks related to steady state subduction. In the Eocene, during initial steepening subducting slab explosion of shoshonites occurred. Further steepening and upwelling of asthenosphere resulted in formation of the Talysh backarc (Fig. 11), where Middle Eocene tholeiite subalkali olivine basalt volcanics, are similar with those which are described in the Achara-Trialety interarc. However here we have similar sequence as in Achara-Trialety and Black Sea minor ocean, but here we have some distinctions as well. In the Achara-Trialety Middle Eocene Tholeiite basaltic series transferred in upper sequence in the shoshonite-trachyandesite suite, according to temporal slackening of rifting. In Talysh, it is overlaid by Late Eocene volcano-sedimentary

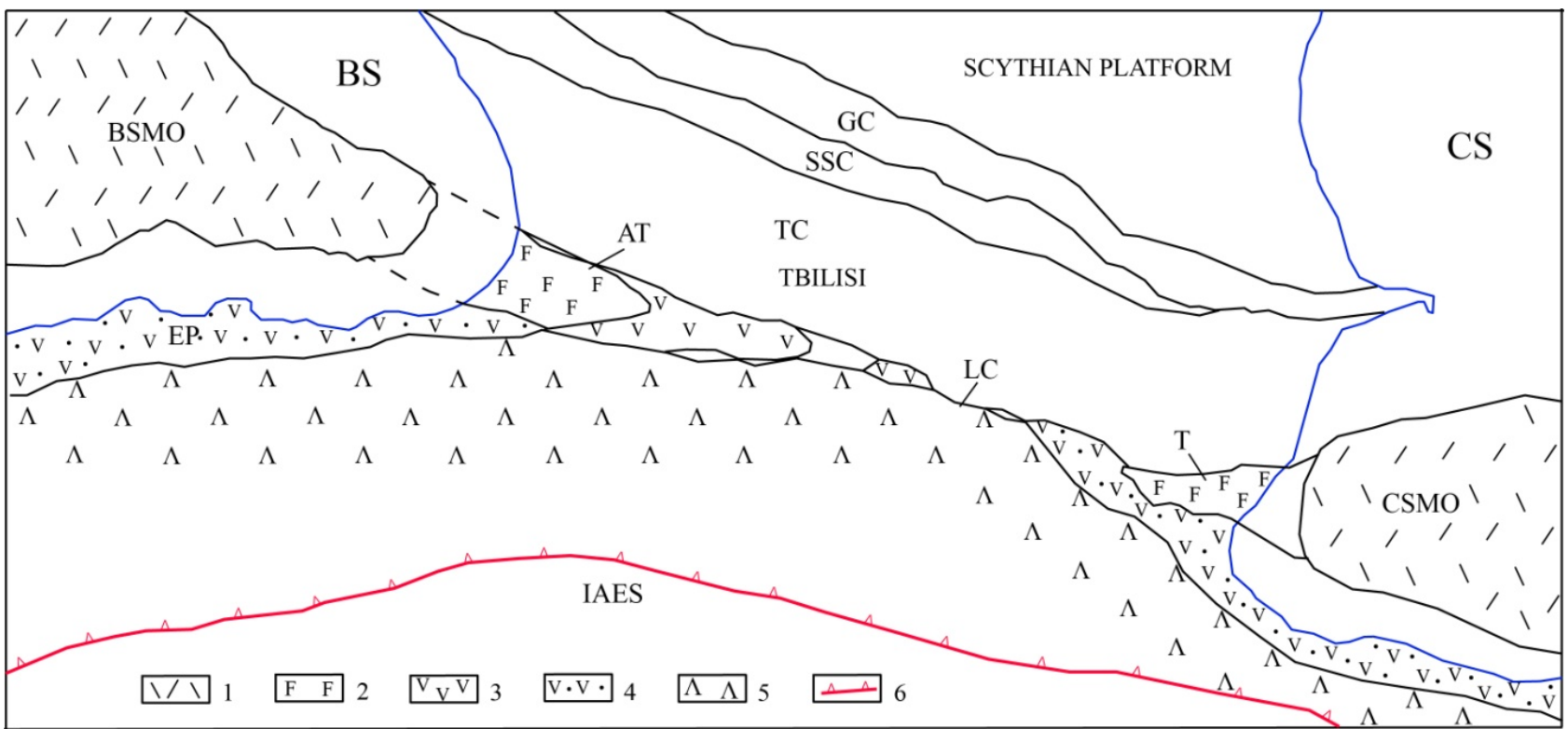

Fig. 11 Schematic map reflects the E-W lateral geodynamic transformation of subducted slab above IAES suture, showing the character of the Eocene volcanic series in the East Pontides and Lesser Caucasus.

1-Ophyolites, 2-Alkaline olivine basalts and tholeiites of backarc settings, 3-Eocene calcalkaline volcanic series of island arc, 4 - Shoshonite series, 5-Cretaceous calc-alkaline series of island arc. BS-Black Sea, CS - Caspian Sea, GC-Great Caucasus, SSC-Southern Slope of Caucasus, TC-Transcaucasus, AT-Achara-Thrialety, LS-Lesser Caucasus, EP_East Pontides, BSMO_-Black Sea Minor Ocean, T-Talysh 
rocks cut by peridotite, picrite and gabbro-peridotite stocks and dikes. The Talysh backarc extends eastward into Caspian Sea minor ocean basin [12].

It is noteworthy, that in the Achara-Trialety during Middle to Late Eocene mantle influence was slackening and subsequently the Late Eocene is marked by formation of shoshonite and calc-alkaline rocks. In contrast, in Talysh mantle influence increased in the Late Eocene and led to formation of a minor ocean setting with emplacement of alkali-ultramafic peridotite stocks.

\section{Post-collision Metallogeny, Magmatism and Hydrothermal Alteration}

The convergence of Eurasian and Afro-Arabian continents was determined by closure of Tethys Ocean. Stress of the Eurasian margin revealed in transmit of pre- to post-collision development [25]. At post-collision stage subduction ceased, but steepening of subducted slab was continuing resulting in intrusive smelting and fold-thrust structuring. The steepening of subducted slab under the thick orogenic crust caused incursion asthenosphere material and streaming high temperature mantle fluids. The hot fluids stipulated leaching of gold and trace metals $(\mathrm{Sb}, \mathrm{W}, \mathrm{Mo}$ and $\mathrm{Hg}$ ) from orogenic crust and determined post-collision metallogeny. At the post-collision development mineralization and orogenous intrusive activity were related to fold-thrust zones and in studied region everywhere from Iran, Caucasus, Turkey and Balkan-Carpathians are dated by Oligocene-Miocene determined by grano-diorite syn- and post-orogenous intrusive activity. The mineralization includes porphyry and epithermal gold-base metal ores, low sulfidation goldbearing quartz-antimony, sheelite, wolframite and mercury vein-stockwork mineralization. As the porphyry, so low-sulfidation ores are associated with trace metals (Sb, W, Mo and $\mathrm{Hg}$ ). In the studied region, the post-collision settings and related metallogeny were investigated in magmatic belts of Ahar-Arasbaran, Alborz-Azerbaijan,
Central Iran Block and in the Sanandaj-Sirjan zone (Fig. 12), as well as in the Main Range of Caucasus and its Southern Slope, so in Lesser Caucasus and in Menderes Massive (Turkey) (Fig. 6). The post-collision mineralization in Iran occurs in Cenozoic porphyry deposits of Sungun and Mazra, the epithermal deposits of Harvana group (Mivehrud, Anderian, Astargan, Halfian etc.), Muteh deposit of Sanandaj-Sirjan zone, as well as by deposits of the East Iran magmatic belt-Zarshuran, Akdareh, Kom, Daskesan etc. (Fig. 12). All these deposits are presented by gold-bearing and lode type base metal mineralization and non-sulfide and low-sulfidation veins and stockworks. That is all related to Oligocene-Miocene dacite-granodiorite and granite intrusive stocks cross-cutting Paleozoic and Mesozoic rocks. The stocks serve as pathways for fluids streaming from deep-seated magmatic chambers, which moved along these stocks and system of faults and shear zones in the rocks of various ages. The gold mineralization, as well as sulfide, low- and non-sulfide ores associates with above mentioned trace metals.

At the Mivehrud deposit (Harvana group), the gold mineralization coincides with $\mathrm{Sb}, \mathrm{W}$, Mo association. Gold-bearing quartz-antimony veins and their host rocks are associated with $\mathrm{Sb}, \mathrm{Mo}, \mathrm{Zn}, \mathrm{Pb}, \mathrm{Te}$ and $\mathrm{Se}$. The geochemical background of the host rock Harvana group of deposits consists of $\mathrm{Cu}$ : 200-253 ppm, Au: 88-121 ppm, Mo: 3.0-5.7 ppm, W: 6.3-7.1 ppm, Pb: 120-517 ppm, Zn: 121-160 ppm, Sb: 7.10 ppm.

In the Mivehrud deposit, gold-base metal ores contain $\mathrm{Zn}-\mathrm{Ag}-\mathrm{Sb}$ and $\mathrm{Pb}-\mathrm{Bi}$ oxides and silver-bearing quartz-antimony veins.

In the Alborz magmatic belt, Central Iran Block and in Sanandaj-Sirjan zone gold-copper-porphyry and gold-base metal lode and stockwork mineralization are controlled by Oligo-Miocene dacite, grano-diorite porphyry and granite intrusive stocks, which cut Paleozoic and Mesozoic complexes of rocks [28]. 

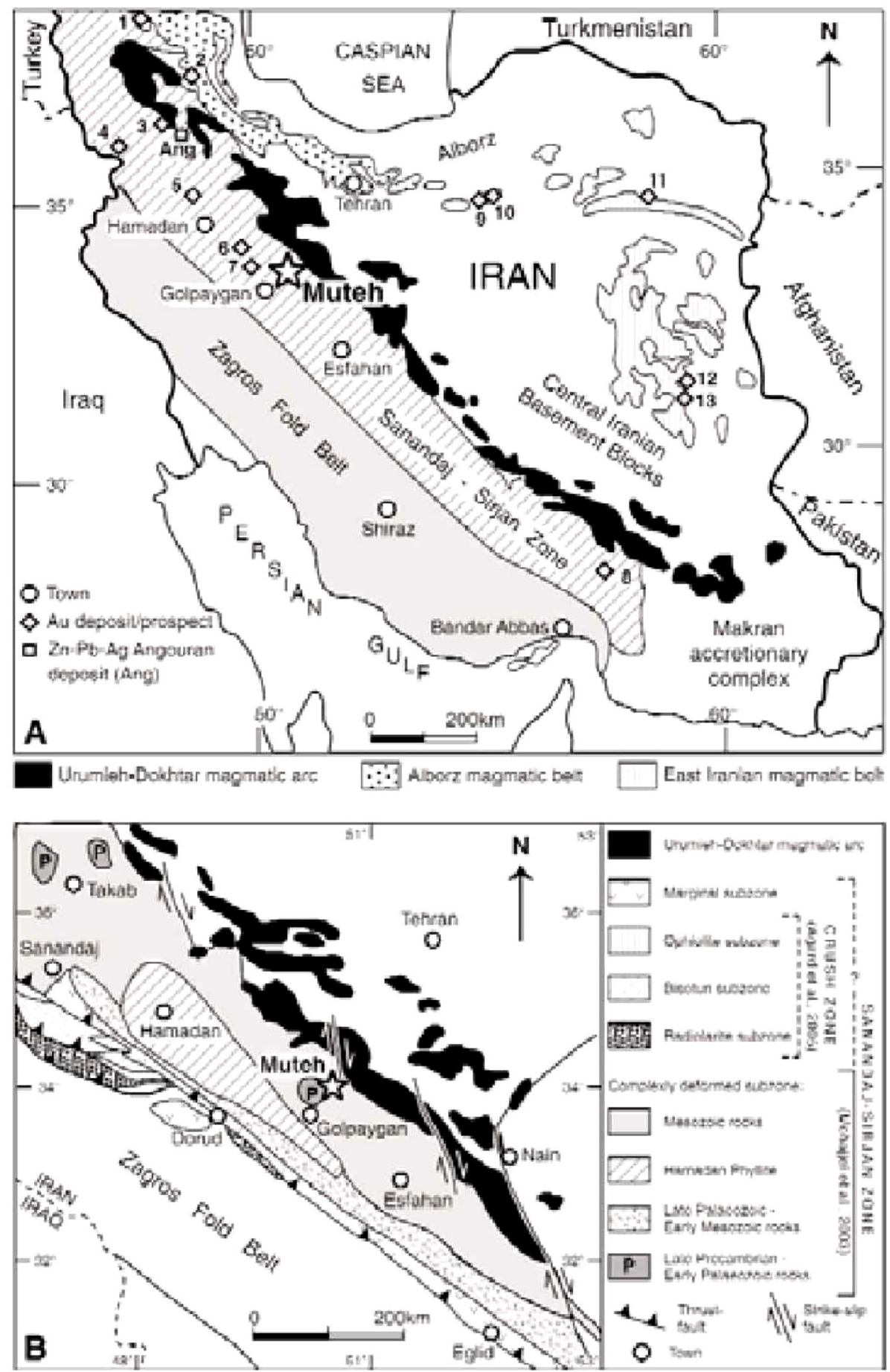

Fig. 12 Main tectonic elements and Mesozoic-Cenozoic magmatic belts of Iran after Stöcklin, and Alavi, et al., and location of gold occurrences, prospects, and mines in Iran.

1-Kharvana, 2-Mianeh, 3-Zarshuran-Agh Darreh, 4-Kervian, 5-Dashkasan-Baharlu, 6-Ahangaran, 7-Astaneh, 8-Zartorosht, 9-Gandy-Abolhassani, 10-Kuh-e Zar, 11-Chelpow, 12-Qal'eh Zari, 13-Shalir (locations are from Lescuyer et al., 2003, except location 4 from Heidari et al., 2006, locations 6-8 from www.gsi.ir, and location 9 from Shamanian et al., 2004). Ang-Miocene Angouran $\mathrm{Zn}-\mathrm{Pb}-\mathrm{Ag}$ deposit linked to metamorphic core complex exhumation in the Sanandaj-Sirjan zone (Gilg et al., 2006). B-Simplified tectonic map of southwestern Iran, showing the subdivision of the Sanandaj-Sirjan tectonic zone. There is still a matter of debate about the attribution of the Ophiolite, Bisotun, and Radiolarite subzones; Mohajjel et al., (2003) include them in the Sanandaj-Sirjan tectonic zone, whereas Agard et al., (2005) group them in a separate zone of Arabian affinity termed the Grush zone [28]. 
Gold-copper-base metal mineralization associated with $\mathrm{Sb}, \mathrm{Mo}, \mathrm{Hg}$ and $\mathrm{W}$, is known in the East Iran magmatic belt and is presented by the Carlin type deposit Zarshuran, the Agh-Dareh prospect, the Dash kesan and Binalud gold-bearing lead-zinc deposits and Hash-Zadehan base metals and gold-antimony ore field, where Paleogene turbidites are cut by Oligocene-Miocene subvolcanic and hypabyssal granitoids, which controlled mercury and antimonite mineralization. Thus post-collision gold mineralization related to Oligocene-Miocene magmatic province of Iran (Fig. 12) is characterized by coinciding with trace metal association- $\mathrm{Sb}, \mathrm{W}$, Mo and Hg.

The post-collision setting is continuing from Iran to the Lesser Caucasus, in the Meghri-Ordubad Cenozoic magmatic province, where significant gold-molybdenum mineralization associated with $\mathrm{Sb}$, $\mathrm{W}$ and $\mathrm{Hg}$ is related to Oligocene-Miocene granitoid stocks. The significant gold deposits of Zod and Merhadzor consist of gold-bearing quartz-antimonite mineralization and are located along the Sevano-Akera suture and controlled by Cenozoic granodiorite-porphyry intrusive stocks [29].

The post-collision gold mineralization coincided with trace metals ( $\mathrm{Sb}, \mathrm{W}, \mathrm{Mo}$ and $\mathrm{Hg}$ ) occurring in the fold-thrust zone of Caucasus (Fig. 10IV). Here the most significant is Zopkhito deposit, which was explored and studied in detail by geologist Sh. Khaduri (reports of Geological Survey of Georgia 1980-1990 years). The mineralization consists of gold-bearing quartz-antimonite and gold-copper-base metal ores. The ore wall alternation is presented by quartz-sericite-pyrite, and coincides with antimonite. Ore-bearing veins cross-cut Lower Jurassic schysts, which are cut by Oligocene-Miocene granodiorite stocks. The gold content of veins is $4.35 \mathrm{ppm}$, silver- $4.15 \mathrm{ppm}$. The gold reserves exceed $34 \mathrm{t}$, reserves of $\mathrm{Sb}-41,223 \mathrm{t}$, silver-39 t.

The other significant object here is Lukhumi deposit with gold-arsenopyrite-antimonate mineralization. It is controlled by shear zones developed in Upper-Liassic schysts and limestones, where quartz-antimonite-realgar-orpiment and quartz-sheelite stockworks occur. The gold grade in vein is $5.10 \mathrm{ppm}, \mathrm{As}-6.7 \mathrm{ppm}, \mathrm{Sb}-7.37 \mathrm{ppm}$. The ore reserve is $483,000 \mathrm{t}$, including $14.40 \mathrm{t} \mathrm{Au}, 2,580 \mathrm{t}$ $\mathrm{Sb}$ and $1,800 \mathrm{t}$ As.

In the Caucasus mountain range, the Okrila-Achara prospect occurs, controlled by a regional fault [30], where gold is associated with $\mathrm{Sb}$ and W. Gold mineralization occurs as quartz-sheelite, quartz-base metals and gold-bearing quartz veins. Ore wall rocks are silicificated, chloritized and sericitized. The gold grade in ores coincides with $\mathrm{Sb}$ and $\mathrm{W}$.

In the Caucasus numerous trace metals prospects are known. Among them are the Carobi molybdenum deposits (reserve $50 \mathrm{t}$ of Mo). Prospect Notsara with sheelite mineralization: $\mathrm{W}-3.5 \%, \mathrm{Au}-2.30 \mathrm{ppm}(50$ $\mathrm{t} \mathrm{W}$ and $18,882 \mathrm{~kg} \mathrm{Au}$ ). The mineralization is controlled by Cenozoic granitoid stocks. There are, also, mercury prospects: Akkey: $\mathrm{Hg}-0.34 \%$ (reserve 2,546 t) and Akhahcha: $\mathrm{Hg}-0.5 \%$ (reserve 2,200 t). Antimony participates in the mercury mineralization. Mineralization is located in the Lower Jurassic schist and controlled by faults and shear zones.

The post-collision gold mineralization associated with $\mathrm{Hg}$ and $\mathrm{Sb}$ is known in the Menderes Paleozoic (West Anatolides) presented by Cungurlu, Emerli and Halicoy deposits (Fig. 6). They are controlled by Cenozoic fault and shear zones. The gold mineralization here is associated with $\mathrm{Sb}, \mathrm{W}$ and $\mathrm{Hg}$ [31].

Fault-controlled post-collision Cenozoic gold mineralization is also known in the mineralization Rhodepean Ada-Tepe deposit (Bulgaria), as well as in the Slovakian Carpaths where gold-copper-base metal mineralization coincides with Sb-Hg-As [32].

Thus, the Oligo-Miocene post-collisional mineralization in the studied region is everywhere controlled by fold-thrust zone and orogenous granodiorite porphyry and dacite stocks, cut the 


\section{Volcanism and Metallogeny of Eurasian Active Margin}

Phanerozoic host rocks of different ages (from Paleozoic to Cenozoic). The mineralization is represented by gold-copper-porphyry and low-sulfidation vein stockwork gold and trace metal ( $\mathrm{Sb}, \mathrm{W}, \mathrm{Mo}$ and $\mathrm{Hg}$ ) ores. The mentioned trace metals association comprises gold-copper porphyry base metal, so low-sulfidation ores widespread in the host rocks.

The geochemical indicator of this stage of post-collision development is the association of trace metals ( $\mathrm{Sb}, \mathrm{W}, \mathrm{Mo}$ and $\mathrm{Hg}$ ) forming background of the mineralization and of host rocks. The situation occurred in the studied regions of Iran, Caucasus and Turkey of the Central part of Eurasian margin. The age of syn-orogenic intrusions is Oligocene-Miocene. They coincide with the association of trace metal indicators of the post-collisional setting. Therefore the termination of subduction, ocean closure, the related orogenesis and magmatic activity is dated as Oligocene-Miocene. The next stage of the post-collision process was expressed by Pliocene-Quaternary volcanic activity.

The relation of post-collision volcanism with geodynamic development is studied in detail by Dilek, et al. [33]. Their study area encompasses Arabia, Iran, the Lesser Caucasus and East Turkey. They investigated post-collision calc-alkaline dacitic, shoshonite-trachyandesite and tholeiitic-alkalic basaltic volcanism and detected the spatial and temporal impact of the astenosphere on the character of volcanism. The first stage of volcanic activity is Late Miocene-Early Pliocene revealed in shoshonite-trachyandesite volcanism, later the Pliocene-Quaternary began tholeiitic-alkalic basaltic volcanic activity, characterized by an increasing growth of mantle influence manifested in the tholeiitic-alkalic basaltic volcanic activity. By petrochemical and geochemical criteria, it is similar to pre-collision interarc-backarc volcanism; however it is not characterized by rifting and is characterized by fissure eruptions from deep-seated chambers.
Mineralization is not related to post-collision volcanic activity.

In the studied region, Oligocene-Miocene dacite-porphyry and grano-diorite porphyry magmatism and gold-copper-porphyry and low-sulfidation gold mineralization precede post-collision volcanic activity. The mineralization is associated with widespread rare metals ( $\mathrm{Sb}, \mathrm{W}$, Mo and $\mathrm{Hg}$ ). At this stage of post-collision development, the association of rare metals is an indicator of the post-collision setting.

The similar situation is characteristic for post-collision setting regions worldwide. The gold and association of trace metals are detected in the Tethys-Eurasian metallogenic belt exemplified by the Muruntau group of deposits. In the Altaid orogen at the Late Paleozoic, stage of its collision generation of giant gold deposits (Muruntau, Kumtor, Cholboy and etc.) is related to the final amalgamation and collage stage in the Tianshan Province [34]. The gold mineralization here is associated with $\mathrm{Sb}$, Mo and $\mathrm{W}$.

In the Kumtor deposit, we have a $\mathrm{Au}, \mathrm{W}, \mathrm{Cu}, \mathrm{Te}$, $\mathrm{Ag}, \mathrm{Pb}, \mathrm{Sn}$ and $\mathrm{Sb}$ association; In the Muruntau deposit: $\mathrm{Au}, \mathrm{As}, \mathrm{W}, \mathrm{Bi}, \mathrm{Te}$, and $\mathrm{Cu}$; In the Cholboy deposit: $\mathrm{Au}, \mathrm{Sb}, \mathrm{Hg}, \mathrm{Pb}, \mathrm{Mo}, \mathrm{W}$ and $\mathrm{Cu}$; In the Dauguztau and Amantaitau deposits: $\mathrm{Au}, \mathrm{Ag}, \mathrm{As}, \mathrm{Sb}$, $\mathrm{Mo}$ and $\mathrm{Cu}$.

The similar association of gold with trace metals occurs in the Tombstone gold belt of Yukon (Canada). Here, the post-collision mineralization is related to Cretaceous and Jurassic orogenesis and is controlled by syn-orogenic intrusions [35]. Post-collision development here was linked to Triassic-Cretaceous convergence between the North American and Farallon plates, which led to the collision of oceanic terranes with the continental margin. Here, gold mineralization goes with $\mathrm{Te}, \mathrm{Bi}, \mathrm{As}, \mathrm{W}$ and $\mathrm{Sb}$ association and is related to quartz veins in association with $\mathrm{W}, \mathrm{Au}, \mathrm{Ag}, \mathrm{Pb}, \mathrm{Zn}$ and $\mathrm{Sb}$ [35].

Similarly, in the Western Lachlan orogeny, Southern Australia, syn-collision orogenic gold mineralization is followed by the $\mathrm{Bi}, \mathrm{Te}, \mathrm{As}, \mathrm{W}, \mathrm{Mo}$, 
$\mathrm{Sn}$ and $\mathrm{Sb}$ association.

Consequently, the most significant gold deposits in association with $\mathrm{Sb}, \mathrm{W}, \mathrm{Hg}$ and $\mathrm{Mo}$ are related to post-collision orogenesis and magmatic activity. Among them are giant gold deposits: Muruntau $(\mathrm{Au}-175 \mathrm{Moz})$, Kumtor $(\mathrm{Au}-19 \mathrm{Moz})$, and Zarmitan (Au-11.2 Moz).

It should be mentioned that $\mathrm{Sb}, \mathrm{W}, \mathrm{Hg}$ and $\mathrm{Mo}$ are associated with gold deposits related to post-collision orogenic and intrusive activity and have not been defined in pre-collision backarc, interarc and oceanic settings aside from molybdenum which participates in island arc setting mineralization. The latter is not characterized by the tendency of $\mathrm{Sb}, \mathrm{W}$, and $\mathrm{Hg}$ participation. At the same time in the studied region such giant Mo-deposits as Kajaran are related to post-collision setting.

Therefore, the post-collisional process in the studied region consists of two stages. The first-Oligocene-Miocene is related to post-collision tectonics and granitoid magmatic activity and is presented by gold-copper porphyry, base metal and epithermal low sulfidation gold mineralization in association with trace metals ( $\mathrm{Sb}, \mathrm{W}, \mathrm{Mo}$ and $\mathrm{Hg}$ ) and deposits of these trace metals in particular. The trace metals at the same time are geochemical indicators of postcollision setting. The postcollision process post-dates pre-collision rock complexes of various ages. The mentioned trace metals are not characteristic for pre-collision setting and present geochemical background of the post-collision process. The next stage of post-collision process is marked by the formation of Pliocene-Quaternary shoshonite-trachyandesite and tholeiitic-alkali-basaltic volcanic rocks characterized by similar geochemical and petrochemical indicators as backarc-interarc volcanic series of pre-collision setting. However, the second stage of post-collision situation is not characterized by rifting and mineralization. The volcanic activity is controlled by fissure eruptions from deep magma chambers.
Thus, post-collision gold-copper-base metal metallogeny is characterized by the following criteria:

- The mineralization resulted in porphyry and epithermal vein-stockwork ores and never stratiform VMS mineralization.

- The mineralization is controlled by fold-thrust zone in orogens and orogenic magmatic activity.

- The post-collision mineralization is characterized by high gold grades associated with rare metals ( $\mathrm{Sb}$, $\mathrm{W}, \mathrm{Hg}$ and $\mathrm{Mo}$ ) as in porphyry and in low sulfidation and nonsulfide ores, also in the host rocks. The trace metals association is the exploration criteria for gold mineralization.

- Trace metals in post-collision setting are introduced in proper deposits of antimony, sheelite, wolframite and mercury.

- Gold and trace metals genesis in post-collision setting is related to the steepening of the subducted slab on the depth and invasion granitoid magma and high temperature fluid flows into the lithosphere. The fluids leached gold and trace metals from thick orogenic sialic crust and formed porphyry and epithermal vein-stockwork mineralization.

- The post-collision setting is characterized by a high geochemical background of trace metals $(\mathrm{Sb}, \mathrm{W}$, $\mathrm{Hg}$ and $\mathrm{Mo}$ ). Accordingly the association of mentioned trace metals simultaneously is the indicator of post-collision setting. It is noteworthy, that in pre-collision setting these trace metals are not present. The only exception is molybdenum.

\section{Discussion and Conclusions}

In the PreCambrian, at plume tectonic activity the formation of modern crust occurred, which consists of sialic, basaltic crusts and rigid upper mantle. At the same time, redistribution of precious $(\mathrm{Au}, \mathrm{Ag})$ and base metals $(\mathrm{Pb}, \mathrm{Zn}$ and $\mathrm{Cu})$ is divided between sialic, basaltic crust and mantle. So, in the Phanerozoic, when plume tectonic was changed by modern plate-tectonics, geodynamic development occurred in the conditions of separated crust and redistributed 


\section{Crustal and Mantle Sources at Various Settings of Phanerozoic Geodynamic Development Expressed in 381 Volcanism and Metallogeny of Eurasian Active Margin}

precious and base metals. The Phanerozoic geodynamic development coincides with volcanic activity and mineralization distinctly observed at Eurasian active margin during evolution of Tethys Ocean, revealed on its Northvergent subduction and collision. The process is developed at pre- and post-collision stages. The pre-collision stage is controlled by steady-state subduction and steepening of subducting slab with incursion of mantle diapir provides rifting and spreading The post-collision stages were revealed in orogenesis according to closure of Tethys Ocean and convergence and stressing of Afro-Arabian continent on the Eurasian margin. At post-collision stage subducting is terminated, but steepening of subducted slab is continuing, revealed in the streaming in thick orogenic crust fluid flows and invasion of mantle material in dip chambers provided post-collision volcanism. However at postcollision stage it is not known rifting is prevented by thickness of orogenous crust.

The pre-collision development occurred during subducting of Tethys ocean slab beneath Eurasian margin. The steady-state subduction is related to island arc setting, calc-alkaline andesite-rhyodacite volcanism and gold-copper-base metals porphyry and Kuroko type mineralization. At this setting transformation of subducting slab and incursion of mantle diaper is not known, however, the oceanic slab is plunged into asthenosphere. Therefore, sialic, basaltic crust and mantle participate here in the process of mineralization. The steady state subduction does not coincide with mantle incursion and mineralization is presumably crustal.

At the incipient stage of inter/backarc setting, the weak steepening of subducting slab occurs in invasion of mantle diapir at the low levels, provoking weak rifting and at this stage sialic crust yet is not spreading out from the zone of volcanism and mineralization. The volcanism here is represented by subalkaly trachyriodacite, trachyandesite and shoshonite and mineralization of $\mathrm{Au}, \mathrm{Pb}, \mathrm{Zn}$ and $\mathrm{Cu}$ pyrite ores similar to the mineralization of steady-state subduction of island arc setting. Au and $\mathrm{Pb}$ here, also, are related to participation of sialic crust at incipient stage of inter/backarc setting.

The above mentioned data are confirmed and exemplified in the studied region deposits and ore districts as Bolnisi ore district (Madneuli and Beqtakari clusters) Panaguirishte ore district (Chelopech, Elashitsa, Vlaikov-Vrfukh deposits), Timok group of deposits (Bor, Maidanpec) Achara-Trialety zone (Merisi, Vakidjvari), etc..

The next full stage of interarc-backarc setting is characterized by strengthening of steepening with incursion of mantle diapir at high levels occurring in intensive rifting and spreading out of sialic crust from zone of mineralization and volcanic activity.

In the studied region, the mentioned data are exemplified in the group of deposits located in the Fore Range of Caucasus-Khudes, Urup-Daud and Filiz-chai group of deposits (Filiz-chai, Kizildere, Catsdag and Adange) in the Southern Slope of Caucasus.

The further upwelling of mantle diapir on the highest level, brings most intensive spreading and minor oceanic settings characterized by ophiolite volcanism, dunite-peridotite magmatism, serpentinization and copper-pyrite mineralization. At this stage the sialic and basaltic crusts are fully spreading out from the zone of volcanism and mineralization and their source of volcanism and mineralization is only mantle. In the studied region, the minor ocean and oceanic setting occurred in Küre Complex and the oceanic suture is divided into the Border field and Tauride terranes. Küre Complex contains the Ashicoy and Bakibaba copper-pyrite deposits, because of lack of gold, lead and zinc, so deposits of Madenkoy (Siirt) and Maden (Elazig) are located in the oceanic suture.

So, volcanic and petrological indicators of oceanic setting are ophiolites and ultramafic dunite-peridotites, whereas the only metallogenic indicators here are 
copper lack of $\mathrm{Zn}, \mathrm{Pb}$ and $\mathrm{Au}$. Whereas, minor ocean and oceanic setting source is only mantle, so copper is only metallogenic indicator of oceanic setting. At the same time, source of calc-alkaline volcanics and $\mathrm{Au}$, $\mathrm{Pb}, \mathrm{Zn}, \mathrm{Cu}$-metallogenic indicators is island arc setting. The same metallogenic indicators are characterized by incipient stage of inter/backarc setting, where sialic crust is participated in zone of volcanic activity and mineralization.

At same time, volcanologic indicators here are trachyrhyolite, trachyandesite and shoshonites. The volcanologic indicators of full inter/backarc setting, where sialic crust is fully spreading out from zone of volcanism and mineralization, are tholeiites and olivine basalts and metallogenic indicators are zinc and copper.

In the studied region at pre-collision stage of development temporal and spatial relationship of subduction is distinctly seen with volcanism and mineralization. The alteration of steady state subduction temporally and spatially to steepening of subducting slab occurs along its northvergent deepening, so laterally to dip from West to East, as well as temporally in ascending succession coinciding with alteration island arc setting in back/interarc and minor ocean, which depended on level of incursion mantle diaper.

The various stage of geodynamic development and coincided with volcanism and mineralization revealed in various scales of mantle and crustal influence on volcanism and mineralization. At the island arc setting crustal influence prevailed and calc-alkaline volcanism occurs confirmed by gold-lead participation in mineralization. In full inter/backarc setting, where sialic crust spreads out from zone of volcanism and ore formation, the mineralization presented $\mathrm{Zn}$ and $\mathrm{Cu}$ and lack of $\mathrm{Au}$ and $\mathrm{Pb}$. At the minor ocean setting the basaltic crusts are also spreading out and the ophiolite volcanism and only cupriferous mineralization occur, with lack of $\mathrm{Au}, \mathrm{Pb}$ and $\mathrm{Zn}$-as well. Therefore, the source of gold and lead is sialic crust and source of copper is the mantle.

The post-collision development in the studied region occurred after collision and closure of Tethys Ocean revealed by the stress of Afro-Arabian continent on the Eurasian margin. It is presented by two stages. The first Oligo-Miocene stage was revealed in orogenesis, fold-thrust structuring on invasion of granodiorite and dacite porphyry stocks. The second Pliocene Quaternary stage occurred as shoshonite, trachyandesite and tholeiite-alkalybasalt volcanic activity. At the first stage of post-collision setting, after closure of Tethys Ocean, the subducted slab was continuing. During the Oligo-Miocene, it was stimulating invasion of high temperature fluid streams along fold-thrust structures and smelting of granodiorite-dacite magma from orogenic sialic crust. The intrusives and fold-thrust structures controlled gold-base metal porphyry mineralization and gold quartz-antimonite, quartz-sheelite, quartz-antimonite, wolframite and quartz-mercury veins and stockworks. The mineralization coincided with association of trace metals ( $\mathrm{Sb}, \mathrm{W}, \mathrm{Mo}$ and $\mathrm{Hg}$ ) leached from thick orogenous crust under high pressure by high temperature fluids ascending along faults and shear zones. The mentioned trace metals comprise the mineralization spreading in ore wall which altered rock and widespread in the orebearing hostrock. They presented the geochemical background of post-collision setting.

The post-collision setting is overlaid on the pre-collision rocks, so the mentioned trace metal association is the distinct geochemical and metallogenic indicator of post-collision setting and might be used to confirm the post-collision activity in the region. The trace metals are characterized by post-collision mineralization in the various region of the world. Among them are giant gold deposits of Muruntau group of Tianshan Province, the Tombstone gold belt of Yukon (Canada), gold deposits of Western Lachlan orogeny of Southern Australia etc. So the trace metals ( $\mathrm{Sb}, \mathrm{W}, \mathrm{Mo}$ and $\mathrm{Hg}$ ) are 


\section{Crustal and Mantle Sources at Various Settings of Phanerozoic Geodynamic Development Expressed in 383 Volcanism and Metallogeny of Eurasian Active Margin}

geochemical and metallogenic indicators of the first stage of post-collision development.

The second stage presents post-Miocene, Quaternary-Pleistocene volcanic activity of andesite, subalkaly basalt and tholeiites characterized by geochemical criteria of the similar pre-collision rocks. They lack geochemical indicator trace metals and are not characterized by rifting and mineralization.

The rifting of pre-collision stage caused by steepening of subducting slab, depended on intensity and scale of incursion mantle diapir at various setting controlled by the participation of sialic, basaltic crust and mantle in volcanism and mineralization, determined by the crustal and mantle influence. Rifting and spreading were controlled by invasion of mantle diapir in inter/backarc and oceanic setting. At the same time, in the island arc setting at the steady-state subducting where incursion of mantle diapir is not determined rifting is not fixed. In the island arc, setting invasion of calc-alkaline granodiorite intrusive stocks is determined, by which the islands are tumiscenced in shallow sea. On the islands, in subaeral condition, ignimbrite ejections and later cauldron subsidence occur. In the back/interarc and oceanic settings, the island tumescence is not known, nor ignimbrite ejections and cauldron subsidence. In island arcs, crustal influence prevailed in volcanism and mineralization, whereas in back/interarc and oceanic setting the mantle influence is prevalent.

\section{Summary}

In the Paleozoic earth crust is divided into sialic, basaltic crust and rigid upper mantle. The precious and base metals are distributed within them. The gold and lead are concentrated in sialic crust, zinc in basaltic crust, whereas copper mainly rests in mantle. During evolution of Tethys Ocean, the oceanic slab is subducting beneath Eurasian margin and collision is related to convergence of Eurasian and Afro-Arabian continents terminated by stress of Afro-Arabian on the Eurasian margin caused by orogenesis. The process of subduction till closure of the ocean represented pre-collision development after the closure and convergence was transferred in post-collision stage.

Pre-collision development is regulated by steady-state subduction and steepening of subducting slab. They are temporally alternating. Steepening is controlled by mantle diapir incursion. The intensity of steepening and diapir incursion alternates temporally and spatially and controlled mantle and crustal influence on the volcanic activity and mineralization and determined settings of geodynamic development. The steady state subduction occurs without steepening of slab, so here it lacks incursion of mantle material. At this stage volcanism and mineralization had mainly crustal influence/and were related to island arc setting. It is not characterized by rifting, because rifting was caused by mantle diapir incursion, but here invasion of granodiorite stocks occurred. The latter tumiscenced bottom of sea end emerged the islands. On the island, ignimbrite ejections took place terminated by cauldron subsidence. The tumescence of sea bottom, island emerging and cauldron subsidence provoke block tectonics and island arc setting, whereas inter/backarc setting is characterized by rifting extension without dlocking [36]. The tumescence of sea bottom, island emerging and cauldron subsidence occur in block tectonics at island arc setting, whereas inter/backarc setting is characterized by extension without blocking. On the island at subaerial condition gold-copper-base metal porphyry and epithermal low-sulfidation gold mineralization occurred, whereas in the sea, at the subaqual condition Kuroko type VMS ore formation of the same content occurred. Island arc volcanic activity presented basalt-andesite-rhyolite. Those are volcanological indicators, whereas $\mathrm{Au}, \mathrm{Pb}, \mathrm{Zn}$ and $\mathrm{Cu}$ mineralization is the matallogenic indicator of island arc setting. Volcanic activity and mineralization of island arc setting were determined by participation of sialic, basaltic crust, so as the mantle because of subducting slab is plunged beneath the crust into 


\section{Crustal and Mantle Sources at Various Settings of Phanerozoic Geodynamic Development Expressed in Volcanism and Metallogeny of Eurasian Active Margin}

asthenosphere. The same metallogenic indicators are characterized by incipient stage of inter/backarc setting. At the same time, volcanologic indicators here are presented by subalkaly thrachyrhyodacite, trachyandesite, shoshonite and trachybasalt. This stage is characterized by weak steepening of subducting slab and consequently by weak mantle incursion, and provokes weak rifting and subalkaly volcanism. At this stage, the sialic crust - the reason of consistence of gold and lead as metallogenic indicators, participated in process of volcanism and mineralization. At the same time, subalkaly nature of volcanism is caused by weak mantle influence.

The next stage of development in full interarc/backarc setting related with strengthen steepening, incursion of mantle diapir and intensive rifting. The rifting spreads out the sialic crust from zone of volcanism and mineralization. So, here, volcanism and mineralization are presented by tholeiite-olivine basalt volcanism and copper-zinc mineralization due to lack of gold and lead. The source of zinc here is basaltic crust and source of copper is mainly mantle diapir.

The further strengthening of steepening of subducting slab and incursion of mantle diapir on the highest level occurred in most intensive spreading, which spread out from zone of volcanism and mineralization the basaltic crust and only source of volcanic activity and ore formation here become the mantle. So, the inter/backarc here transferred in the minor ocean and ocean setting. The volcanological and petrological indicators of this stage are ophiolite volcanism, dunite-peridotite ultramafic magmatism and serpentinization. The only metallogenic indicator here is copper in copper-pyrite Cyprus type mineralization. The lack of gold, lead and zinc in this setting where basaltic crust does not participate, nor sialic crust, confirms that sources of zinc are in basaltic and gold and lead are in sialic crust.

Thus, volcanologic indicator of island arc setting is calcalkaline volcanism (basalt-andesite-rhyodacite) and metallogenic indicators are $\mathrm{Au}, \mathrm{Pb}, \mathrm{Zn}$ and $\mathrm{Cu}$. The indicators of fully inter/backarc setting are tholeiite-olivine basalt volcanism and $\mathrm{Zn}-\mathrm{Cu}$ mineralization, lack of $\mathrm{Au}$ and $\mathrm{Pb}$.

Volcanological and petrological indicators of the oceanic setting are ophiolites, dunite-peridotite, and serpentinization, whereas metallogenic indicator is only $\mathrm{Cu}$, lack of $\mathrm{Au}, \mathrm{Pb}, \mathrm{Zn}$. Thus, all pre-collision settings are volcanologically and metallogenically indicated. The indication confirmed by geochemical criteria of ${ }^{87} \mathrm{Sr} /{ }^{86} \mathrm{Sr} .{ }^{87} \mathrm{Sr} /{ }^{86} \mathrm{Sr}$ ratio of island arc calc-alkaline volcanic equals $0.710-0.715$, ratio of backarc setting tholeiites is 0.7034 , whereas ratio of minor ocean ophiolites is 0.7023 .

The transferring temporally and spatially of pre-collision setting was exemplified in the Caucasus and Balkan regions, where Black sea minor ocean laterally to East transferred to interarc rift of Achara-Trialety zone to west to Burgas backarc. So, Talysh backarc (Azerbaijan) transmits to east into Caspian minor ocean. At the same time, Achara-Trialety interarc rifting is characterized by laterally slackening and transferred to incipient stage and further in island arc setting. In Achara-Trialety interarc is determined temporally by slackening rifting in ascending succession and it transferred to incipient stage. At the same time, in Talysh backarc in ascending succession extrusion dunite-peridotite stocks and veins occurs, evidencing the oceanic indicator. All described transferring depended on various scale of steepening of subducting slab related to different level and strength of diapir incursion at pre-collision development.

At post-collision development subducting is terminated, but steepening of subducting slab and crustal-mantle interrelation is continuing. The post-collision development occurs in two stage. The first was revealed in protracted streaming of high temperature fluids in thick orogenic crust, along the faults and shear zones. They are smelting granodiorite magma from sialic crust and leaching gold and trace 


\section{Crustal and Mantle Sources at Various Settings of Phanerozoic Geodynamic Development Expressed in 385 Volcanism and Metallogeny of Eurasian Active Margin}

metals-Sb, W, Mo and $\mathrm{Hg}$. Here granodiorite porphyry stocks faults and shear zones controlled gold-base metal porphyry and low sulfidation gold-antimonite, gold-sheelite, wolframite and mercury goldbearing deposits. As porphyry so low-sulfidation deposits comprise of trace metals association transferred in ore wall which altered rocks and widespread in the orebearing hostrocks.

\section{Acknowledgements}

Author is very grateful to Prof. Richard Goldfarb (USGS) and Prof. Robert Moritz (University of Geneva) for critical review and comments that help very much in improving presented material as well as Prof. Shota Adamia and Dr. David Zakaraia for analyzing geology of the Eurasian active margin.

\section{References}

[1] Gugushvili, V., Popkhadze, N., Beridze, T., and Khutsishvili, S. 2010. "Sources of Base, Precious and Rare Metals during the Tethyan Evolution of the Caucasus and Pontides." In Proceedings of the XIX $C B G A$ Congress, Thessaloniki, Greece, Special volume 100, 333-41.

[2] Goldfarb, R. G., Groves, I., and Gardol, S. 2001. "Orogenic Gold and Geologic Time: A Global Synthesis." Ore Geology Reviews 18: 1-75.

[3] Groves, D. I., Goldfarb, R. G., Robert, F., and Hart, C. J. R. 2005. "Gold Deposits in Metamorphic Belts: Overview of Current Understanding, Outstanding Problems Future Research and Exploration Significance." Economic Geology 98: 1-29.

[4] Gugushvili, V. 2015. Precollision and Postcollision Metallogeny of Gold-Copper-Base Metal Ores at the Phanerozoic Evolution of Tethys Ocean, edited by Sh. Adamia, R. Goldfarb and R. Moritz, Iv. Javakhishvili Tbilisi State University, Al. Janelidze Institute of Geology, Tbilisi, 131.

[5] Gugushvili, V. 2017. Precollision and Postcollision Geodynamic Evolution of the Tethys Ocean and Its Relation with Regional Metamorphism Hydrothermal Activity and Metallogeny along the Eurasian Continental Margin, edited by R. Goldfarb, R. Moritz, G. Zakariadze. Iv. Javakhishvili Tbilisi State University, Al. Janelidze Institute of Geology, Tbilisi, New Series, V. 129. 180.

[6] Gugushvili, V. 2018. The Regional Metamorphism, Volcanism and Metallogeny at the Eurasian Continental
Margin Controlled by Geodynamic Regime of Phanerozoic Subduction and Collision of Tethys. Norderstedt, Germany: LAP LAMERT Academic Publishing, 65.

[7] Von Quadt, A., Moritz, R., Peycheva, J., and Heinrich, C. A. 2005. "Geochronology and Geodynamics of Late Cretaceous Magmatism and $\mathrm{Cu}-\mathrm{Au}$ Mineralization in the Panaguirishte Region of Apuseni-Banat-Timok-Srednegorie Belt." Ore Geology Review 5 (20): 1-28.

[8] Jancovic, S. 1977. "The Tethyan-Eurasian Metallogenic Belt." Mineralium Deposita 12: 37-47.

[9] Moritz, R., Kouzmanov, K., and Petrunov, R. 2004. "Late Cretaceous $\mathrm{Cu}-\mathrm{Au}$ Epitermal Deposits of the Panaguirishte District Srednegorie Zone.” Schweizerisce Meneralogische and Petrografische mi Heilungen, 79-99.

[10] Shavishvili, I. D. 1983. "Variscan Volcanism in the Caucasus.” IGCP Project N5, Newsletter, 169-79.

[11] Lordkipanidze, M., Zakariadze, G., and Popolitov, E. 1979. "Volcanic Evolution of Marginal and Interarc Basins." Tectonophysics 57: 71-83.

[12] Lordkipanidze, M., Meliksetian, B., and Djarbashian, R. 1988. "Mesozoic-Cenozoic Magmatic Evolution of the Pontian-Crimean-Caucasian Region." Memoire de la Societe Geologique de France, Nouvelle Serie, Paris 154 (2): 103-10.

[13] Lomize, M., and Panov, D. 2000. “Amagmatic Initial Stage of Subduction at the Crimea-Caucasus Margin of the Tethys." Geotectonika 4: 78-92.

[14] Gugushvili, V., Beridze, T., Khutsishvili, S., and Migineishvili, R. 2016. "Phanerozoic Metallogeny of the Caucasus Region during the Tethys Ocean Subduction and at Post-collision Stage." Bulletin of Ac. Sci. of Georgia. 211-8.

[15] Florova, T., and Buricova, J. 1977. "Geosyncline Volcanism (Exemplified on the Southern Slope of Ural)." Moscow State University, Moscow, 263.

[16] Ustaömer, T., and Robertson, A. 1997. "Tectonic-Sedimentary Evolution in the North-Tethyan Margin in the Central Pontides of Northern Turkey." In Regional and Petroleum Geology of the Black Sea Region. American Association of Petroleum Geologist. Tulsa, Oklahoma, USA 74101, 385.

[17] Güner, I. 1980. "Geologic and Massive Sulfide Ores of Küre Area, Pontides (N. Turkey)." MTA Bull. 93-94: 65-109.

[18] Engin, T. 1994. "Metallic minerals." In Geology and Mineral Resources of Turkey. Mineral Research and Exploration Department, Ankara, 1-48.

[19] Rona, P. A., and Scott, S. D. 1993. "Preface of the Special Issue on Sea from Hydrothermal Mineralization: New Perspectives." Economic Geology 88: 1933-76. 


\section{Crustal and Mantle Sources at Various Settings of Phanerozoic Geodynamic Development Expressed in Volcanism and Metallogeny of Eurasian Active Margin}

[20] Adamia, S., Chabukiani, A., Chkhotua, T., Enukidze, O., and Sadradze, N. 2016. "Tethyan Evolution and Continental Collision in Georgia." In Tectonic Evolution, Collision and Seismicity of Southwest Asia, edited by R., Sorkhabi, In Honor of Manuel Berberian's Forty-Five Years of Research Contributions, Geological Society of America Special Paper, 525, doi10.1130/2016.2525(16).

[21] Dzotsenidze, G. 1948. "Pre-Miocene Effusive Volcanism of Georgia." Monograph-I, Ac. Scie of Georgia, Tbilisi, 407.

[22] Lordkipanidze, M. 1980. "Alpian Volcanism and Geodynamics of Central Segment of Mediterranean Folded Belt." Ac. Scie of Georgia, Dr. Scie. dissertation, Tbilisi, 162.

[23] Baba-Zade, V. M., Kekelia, S. A., Abdulaeva, S. F., and Kekelia, M. A. 2015. "Goldbearing Sulfide Deposits of Island Arc Paleosystems, Their Metallogenic Characteristics and Conditions of Geodynamic Development.” Baku. 275.

[24] Gugushvili, V. 1968. "Cretaceous Volcanism of Georgian Block.” Ac. Scie of Georgia, Tbilisi, 73.

[25] Adamia, S. H., Chabukiani, A., Chkhotua, T., Enukidze, O., Sadradze, N., and Zakariadze, G. 2017. "Tethyan Evolution and Continental Collision in Georgia." In The Geological Society of America, Special Paper, edited by N. Sorkhabi. 52: 1-38.

[26] Stanisheva-Vasileva, G. 1971. "Cretaceous Magmatic Formations in the Burgas Synclinorium." Acad. Sci., Bulgaria. Compte Rendue 24: 121-34.

[27] Mamedov, M. 1996. "Petrology of Late Cretaceous and Eocene Magmatic Formations." PhD thesis, Tbilisi.

[28] Moritz, R., Chazban, F., and Singer, B. S. 2006. "Eocene Gold Ore Formation a Muteh, Sunandaj-Sirgian Tectonic Zone, Western Iran: A Result of Late Stage Extension and Exhumation of Metamorphic Basement Rocks within the Zagros Orogeny." Society of Economic Geologists, Inc. Economic Geology 101: 1497-524.

[29] Melikian, L. S. 1977. "Geology and Structure of the
Mineralization of Zod Deposit." PhD thesis, Armenian Academy of Science.

[30] Okrostsvaridze, A., and Bluashvili, D. 2008. "The Results of Detail Investigation of the Hokrila-Achapara Gold Ore-Mineralization of Great Caucasus." Proceedings of Institute of Geology, New Series 124: 317-29.

[31] Yigit, O. 2009. "Mineral Deposits of Turkey in Relation of Tethyan Metallogeny: Implication for Future Mineral Exploration.” Economic Geology 104: 19-51.

[32] Lordkipanidze, M., Gugushvili, V., Lexa, J., and Stohl, J. 1994. "The Geodynamic Condition of Cenozoic Volcanism and Mineralization of Caucasus and Carpaths." In Proceeding of Slovakian Institute of Geology, Bratislava, 91-110.

[33] Dilek, I., Imamverdiev, N., and Altunkaynak, S. 2010. "Geochemistry and Tectonics of Cenozoic Volcanism in the Lesser Caucasus (Azerbaijan) and the Peri-Arabian Region: Collision Induced Mantle Dynamic and Its Magmatic Fingerprint." Journal of International Geology Review 52 (4-6): 536-78.

[34] Yakubchuk, A., Cole, A., Seltman, R., and Shatov, A. 2002. "Tectonic Setting, Characteristics and Regional Exploration. Criteria for Gold Mineralization in the Altaid Orogenic Collage: The Tian-Shan Province as a Key Example." Society of Economic Geologist 9: 177-201.

[35] Mair, J. L., Goldfarb, R. J., Jonson, C. A., Hart, C. J. R., and Mash, E. E. 2006. "Geochemical Constraint of the Genesis Sheelite Dome Intrusion-Related Gold Deposit, Tombstone Gold Belt." Economic Geology 101: 523-53.

[36] Gugushvili, V., Beridze, T., Chkhotua, T., Khutsishvili, S., and Migineishvili, R. 2018. "Volcanologic and Metallogenic Indicators of the Stages of Geodynamic Development of Eurasia Active Margin and Synvolcanic and Postvolcanic Block Faulting Examplified by Bolnisi Ore District." Tbilisi State University, Institute of Geology, Tbilisi, 123. 